\title{
The Cambrian-Ordovician succession in the Ougarta Range (western Algeria, North Africa) and interference of the Late Ordovician glaciation on the development of the Lower Palaeozoic transgression on northern Gondwana
}

\author{
JeAn-Françols GHienNe, KheIRA BOUMendjel, Florentin PARIS, BLAISE Videt, \\ PATRICK RACHEBOEUF \& HAMID AIT SALEM
}

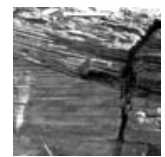

\begin{abstract}
Depositional environments in the 1000-2000 m thick Cambrian-Ordovician succession range from inner-shelf siltstones to fluvial sandstones. Six transgressive-regressive (T-R), low-frequency (15-25 Ma) depositional sequences have been differentiated and correlated with both northern distal (Anti-Atlas, Morocco) and southern proximal (Ahnet, southern Algeria) areas. Sequence 1 ("Lower" Cambrian?) comprises fluvial deposits truncating volcanics and deformed Panafrican basement rocks. Marine strata appeared in Sequence 2 (lower and middle part of the "Middle" Cambrian) but fluvial conditions maintained to the South. Sequence 3 (upper "Middle" Cambrian) is erosionally truncated but further develops to the south, possibly comprising "Upper" Cambrian deposits. In Sequence 4 (Lower Ordovician), fluvial deposits are no longer present and inner-shelf siltstones reached southern Ougarta. Sequences 5 and 6, upper LowerMiddle Ordovician and Upper Ordovician, develop inner-shelf conditions throughout the study area at maximum flooding. Hirnantian glacial strata form a lowstand wedge in the upper part of the Sequence 6 regressive system tract. This succession designates a first-order transgression initiating in the Cambrian. It was temporarily perturbed just before its end by the Hirnantian glaciation. The related erosion led to a discontinuity, angular at basin scale, falsely suggesting a pre-glacial tectonic event. The post-glacial transgression, very fast relative to the Cambrian-Ordovician tempo, resulted in a drastic backstepping of the shorelines that shifted drastically to the south in the early Silurian. After deglaciation, the first-order inversion trend occurred between retrograding strata of the Cambrian-Ordovician succession and the prograding Siluro-Devonian wedge. This event marks in North Africa the maximum flooding of the Lower Palaeozoic megasequence. $\bullet$ Key words: Cambrian, Ordovician, North Gondwana, transgression, glaciation, sequence stratigraphy.
\end{abstract}

\begin{abstract}
Ghienne, J.-F., Boumendjel, K., Paris, F., Videt, B., Racheboeuf, P. \& Salem, H.A. 2007. The Cambrian-Ordovician succession in the Ougarta Range (western Algeria, North Africa) and interference of the Late Ordovician glaciation on the development of the Lower Palaeozoic transgression on northern Gondwana. Bulletin of Geosciences 82(3), 183-214 (14 figures). Czech Geological Survey, Prague. ISSN 1214-1119. Manuscript received June 25, 2007; accepted in revised form September 13, 2007; issued September 30, 2007. • DOI 10.3140/bull.geosci.2007.03.183
\end{abstract}

\begin{abstract}
Jean-François Ghienne, Université Pasteur, CNRS, UMR 7517 Centre de Géochimie de la Surface, Ecole et Observatoire des Sciences de la Terre, 1 rue Blessig, 67084 Strasbourg Cedex, France; JeanFrancois.Ghienne@eost.u-strasbg.fr • Kheira Boumendjel, SONATRACH, Centre de Recherche et Développement, Av. du $1^{\text {er }}$ novembre, 35000 Boumerdès, Algeria $\bullet$ Florentin Paris, Géosciences-Rennes, UMR 6118 du CNRS, Université de Rennes 1, 35042 Rennes-cedex, France; florentin.paris@univ-rennes1.fr・Blaise Videt, the same address as the previous author • Patrick Racheboeuf, UMR 6538 du CNRS, Université de Bretagne Occidentale, 29385 Brest-cedex, France • Hamid Ait Salem, SONATRACH, Centre de Recherche et Développement, Av. du $1^{\text {er }}$ novembre, 35000 Boumerdès, Algeria
\end{abstract}

Stratigraphy aims to subdivide sedimentary successions into correlatable units corresponding ideally to time slices controlled by biostratigraphy. An extensive and thick sedimentary cover has been noted above the Proterozoic basement in the Sahara (Legrand 1985, Fabre 2005, Fabre \& Kazi-Tani 2005), which extends to the east on the Arabian Plate (e.g., Sharland et al. 2001). The first and still useful stratigraphical subdivision was made by Kilian (1922) who proposed to differentiate three units, from base to top: the Internal Tassili, later known as the Cambrian-Ordovician sandstones (e.g., Fabre 1988); the intra-Tassilian trough or depression characterised by the graptolitic Silurian shales; the External Tassili, comprising the upper Silurian and Devonian shales and sandstones. This study concentrates on 


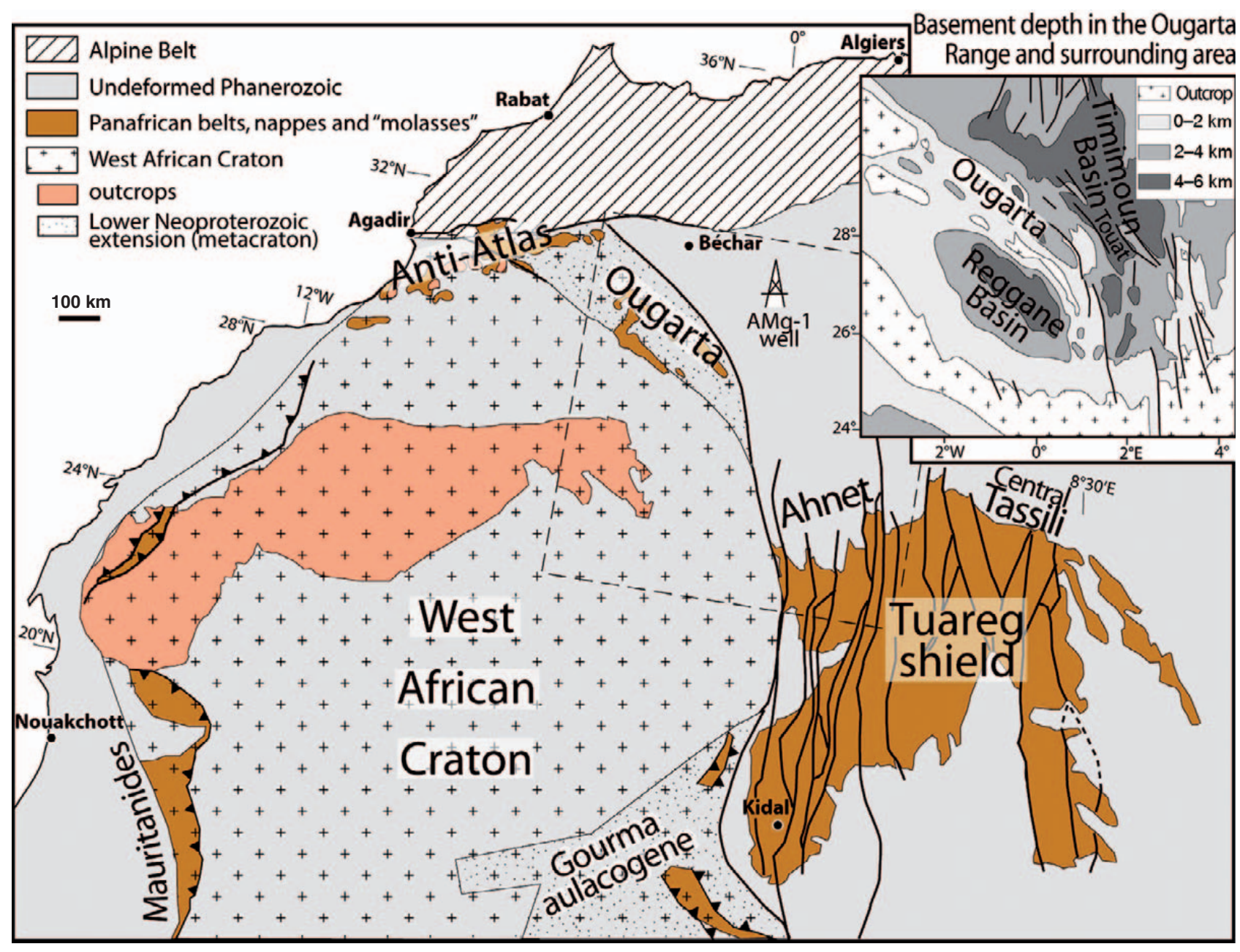

Figure 1. Map of northwestern Africa and location of the Ougarta Range on the northeastern margin of the West African Craton (modified from Ennih \& Liégeois 2001). Basement depths around the Ougarta from Takherist (1990).

the Internal Tassili unit (Cambrian and Ordovician) typified by huge outcrops of quartz-rich sandstones that probably represent the most voluminous siliciclastic sequence ever deposited on continental crust (Burke \& Kraus 2000, Avigad et al. 2005). Geological mapping and extensive work by petroleum geologists in parallel with the discovery of new faunas allowed the Cambrian and Ordovician succession to be further subdivided into four stratigraphic units (e.g., units I to IV in Beuf et al. 1971), comprising a number of formations and members (Legrand 1974, 1985). The fourth unit corresponds to the latest Ordovician (Hirnantian), glacially related succession.

Cambrian and Ordovician strata constitute the lower part of the first-order Lower Gondwana Cycle (Cambrian to Middle Devonian) of Boote et al. (1998) and essentially correspond to the second Arabian Plate tectono-stratigraphic megasequence of Sharland et al. (2001). These strata were dominated over North Gondwana by fluvial to inner-shelf deposits. Correlative biostratigraphic data are relatively sparse with two exceptions: (1) the Anti-Atlas (southern Morocco, e.g., Destombes et al. 1985, ElaouadDebbaj 1988, Gutiérrez-Marco et al. 2003, Bourahrouh et al. 2004) and the Ougarta Range (western Algeria, e.g., Fekirine \& Abdallah 1998, Fabre \& Kazi-Tani 2005), two areas that displayed abundant macrofaunas; (2) palynomorphs (chitinozoans, acritarchs) mainly from drill cores in sedimentary basins (Taugourdeau \& de Jekhowsky 1960, Oulebsir \& Paris 1995, Vecoli 1999, Vecoli \& Le Hérissé 2004, Paris et al. 2007 and references therein). Correlation of these fossil-bearing strata with barren fluvial (or tidal) sandstones in more proximal, southern parts of the platform is still debated even though it is of prime importance in the understanding of the development of Palaeozoic sedimentary basins on the North African cratonic platform.

Therefore, this paper aims firstly to provide a basic sequence stratigraphic framework for the Cambrian-Ordovician succession of the Ougarta Range. Based on outcrop data, a profile nearly parallel to the proximal-to-distal vector will be examined, with in addition correlations pro- 


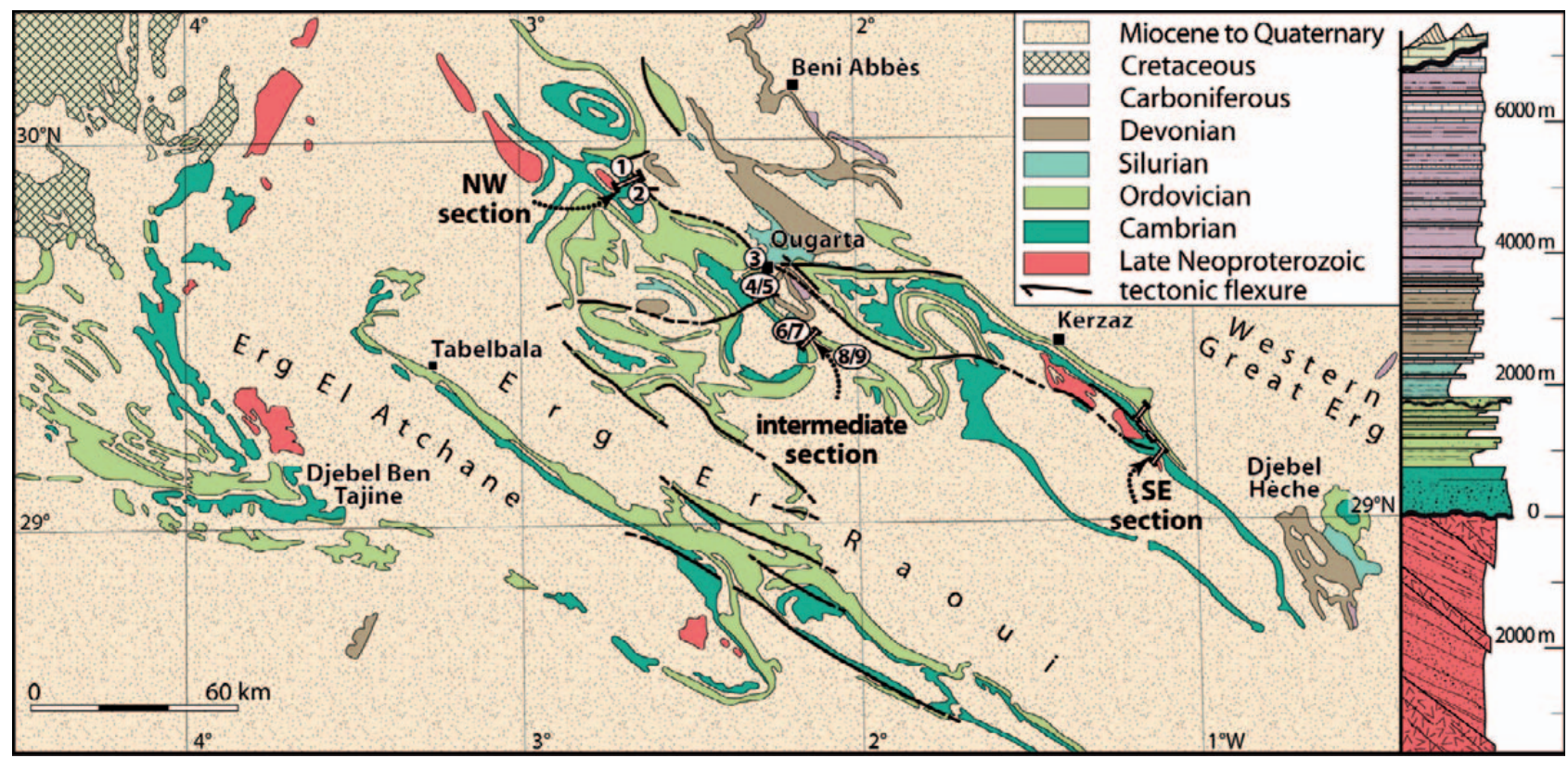

Figure 2. Geological sketch map of the Ougarta Range and synthetic log of the sedimentary succession. The three (NW, intermediate, SE) sections refer to logs in Fig. 4. Numbers (1-9) refer to logs illustrating the Late Ordovician glacial record in Fig. 6.

posed with the Anti-Atlas northward and the Ahnet area southward ( $c a 900 \mathrm{~km}$ from SE to NW, Fig. 1). A number of stratigraphic sequences will be illustrated and a depositional model comprising relationships in time and space from fluvial to inner-shelf deposits will be proposed in the context of the North African cratonic platform. Then, the progressive backstepping of the depositional edge upon the cratonic platform and the signature of intracratonic deformation will be discussed. Finally, the impact of the Late Ordovician glaciation on this otherwise well-organised succession will be examined.

\section{Geological setting}

During the Lower Palaeozoic, North Africa was part of a regionally continuous clastic-dominated North Gondwana platform. Fluvial successions in the SSE graded towards the NNW in storm-to-tide dominated successions. Multiphased Palaeozoic to Mesozoic tectonic uplifts have differentiated several intracratonic basins, the present geometry of which bears little relation to the much broader North Gondwana platform that had an off-shelf gradient towards the NNW during the whole of the Early Palaeozoic (Beuf et al. 1971, Boote et al. 1998, Carr 2002).

The Ougarta Range is one of these uplifts (Fig. 1), bounded by the Reggane Bassin to the West and the Timimoun Basin to the East (Takherist 1990). It corresponds to a folded domain, $120-180 \mathrm{~km}$ in width that trends NW-SE (Fig. 2). Here, thick Lower and Middle Palaeozoic strata overlying Neoproterozoic rocks have been deformed in response to the Variscan compressional event. Thick-skin (Donzeau 1971, 1983) vs thin-skin (Hervouet \& Duee 1996) deformation models have been proposed. This domain, which links the Pan-African NW Hoggar towards the South (Fabre et al. 1988), to the AntiAtlas towards the North (Burkhard et al. 2006; Fig. 1), acted repeatedly as an axis of preferential subsidence on the North Gondwana platform during the Lower Palaeozoic, as evidenced for instance by: (i) the preservation of a "Lower" Cambrian succession correlated with the Adoudounian strata of the Anti-Atlas (Destombes et al. 1985; Fabre 1988, 2005); (ii) an Early Ordovician flooding, resulting in the deposition of graptolite-bearing marine shales delineating an embayment corresponding broadly to the Ougarta domain outlines (Legrand 1985); (iii) an Ordovician to Devonian depocentre (Fabre \& Kazi-Tani 2005). Donzeau $(1974,1983)$ interpreted the Ougarta as an aulacogene structure trending perpendicular to the North Gondwana margin.

It has been proposed recently that the Ougarta Range developed onto the northeastern margin of the West African Craton (Ennih \& Liégeois 2001; Fig. 1). Here, the latest Neoproterozoic post-collisional development of transpressive and then progressively transtensive basins has resulted in first-order, metacratonic, crustal-scale structures. It is proposed that the Lower Palaeozoic depocentre developed on this relatively weaker domain, now integrated to the stable North Gondwana Platform. It has experienced structural inversion during the Variscan event, resulting likely in a thick-skinned uplift of the palaeo-margin of the West African Craton, as documented for instance 



Figure 3 (first part). Exposures in the Ougarta Range. $\bullet$ A - Cambrian strata to the north of the Sebket el Melah (SE section). B - Lower Ordovician strata in the Kheneg el Aatène (intermediate section). $\bullet \mathrm{C}-$ Lower and Upper Ordovician strata in the Kheneg et Tlaïa (NW section).

in the adjacent Anti-Atlas (Donzeau 1974, Faik et al. 2001, Burkhard et al. 2006).

\section{The Cambrian-Ordovician succession in the Ougarta Range}

Pioneering works of Menchikoff (1933), Poueyto (1952), Arbey (1962) and Gomez Silva et al. (1963) proposed the lithostratigraphic nomenclature that is still currently used (Legrand 1985, Fekirine \& Abdallah 1998; Figs 3, 4). The definition of lithostratigraphic units was based on both lithologies and observed bounding discontinuities.

Three sections, representative of the Cambrian-Ordovician succession in the Ougarta Range, have been logged (Figs 2-4). Two of them represent the depositional record at the extremities of a $150 \mathrm{~km}$-long profile, which is oriented from the SE to the NW, i.e. in a direction roughly parallel to the palaeocurrent trend recognised both locally in braided fluvial deposits (dips of cross-strata) and regionally (Beuf et al. 1971). The SE sections (Sebkhet el Mellah and Foum Zeïdiya, Figs 3A, 4C) illustrates proximal depositional environments, whereas the NW section (Kheneg et Tlaïa, Figs 3C-E, 4A), located $150 \mathrm{~km}$ basinward, corresponds to a notably more distal area. In addition, the NW section also represents the sedimentary record of an almost continuously subsiding area characterised by the minor development of erosion surfaces and the development of an exceptionally thick Cambrian-Ordovician sequence. Conversely, the SE section illustrates a depositional record including well defined erosion surfaces. It is then also transitional with areas recognized to the South of the Ougarta 

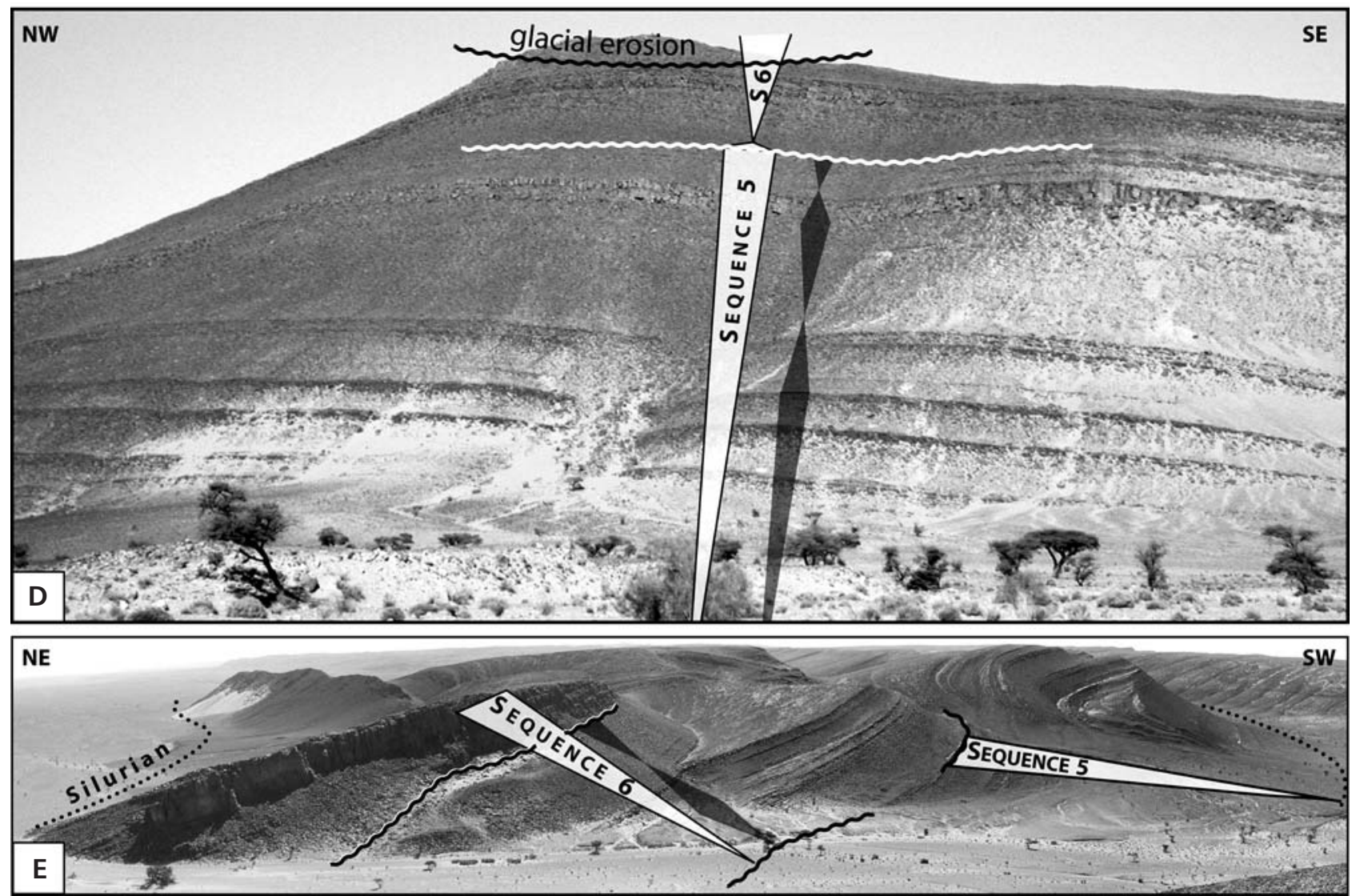

Figure 3 (second part). Exposures in the Ougarta Range. • D, E - Upper Ordovician strata in the Kheneg et Tlaïa (NW section).

where repeatedly uplifted blocks resulted in reduced Cambrian-Ordovician sections (e.g., Djebel Hèche, Legrand 1985). An additional intermediate section shows facies and thickness changes for the Ordovician (Kheneg el Aatène, Figs 3B, 4B).

\section{Pre-glacial depositional facies}

The Cambrian-Ordovician strata in the Ougarta Range show a great variety in facies associations from fluvial coarse-grained sandstones to offshore fines, which are representative of the depositional environments on the North Gondwana Platform (e.g., Beuf et al. 1971, Eschard et al. 2005). Seven depositional environments are basically recognized in the pre-glacial strata: braided fluvial, bioturbated sand-flat, mixed tidal and upper shoreface, upper shoreface, tidal ridges, storm-dominated shoreface and storm-dominated inner shelf deposits. Glacially related depositional environments, uppermost Ordovician in age, are described independently in a separate section.

Fluvial facies association. - The most common fluvial facies constitutes the main part of the Sebkhet el Mellah Fm. and is incidentally present in the Aïn Néchéa Fm. It is made up of coarse to very coarse arkoses or arkosic sandstones, comprising essentially $0.3-1 \mathrm{~m}$ thick, high-angle trough or planar cross-laminated bedsets (Fig. 5A). Sandstones are moderately sorted, with the exception of those underlining large-scale fining-upward successions that contain granules to gravels (NW section, 0-10 m; SE section, 420 and $505 \mathrm{~m}$ ). Rip-up clasts are common; overturned beds rare. Cross-strata consistently dip towards the NW or NNW. Several metres-thick units are identified, some of them punctuated by thin (0.2-1 m thick) Skolithos-bearing sandstone beds. The latter horizons are typically better sorted, more indurated (less arkosic?), contain more rip-up clasts and show reactivation surfaces in well defined trough cross-strata.

The bulk of this association has a fluvial origin as supported by texture and sedimentary structures. The absence of both overbank deposits and channel structures suggests amalgamated braided-fluvial channel deposits, with very large width/depth channel ratios as known in a number of pre-vegetation braidplains (MacNaughton et al. 1997, Long 2004). In the Cambrian setting, intervening bioturbated and more mature horizons indicate episodic shallow-marine conditions, most probably corresponding to 
tidal influences during high frequency transgressive events.

Subordinate coastal plain and estuarine environments have also been identified (NW section (390-410 m and $655 \mathrm{~m}$ ). Very fine-grained, argillaceous and micaceous sandstones interfinger with dm-thick, cross-laminated, bioturbated (mainly Skolithos) sandstone beds with occasional liquefaction structures (overturned cross-strata, flame structures; Fig. 5B). An estuarine or coastal-plain environment with concomitant fluvial and marine influences is proposed for those deposits. At the $390 \mathrm{~m} \mathrm{level}$, they are characteristically underlain by braided fluvial sandstones and overlain by a sharp based, m-thick, cross-stratified bed deposited in an upper shoreface environment (wave ripples, large Diplocraterion).

Bioturbated sand-flat facies association. - Sand-flat deposits occur in thick, rather monotonous sandstone successions in the Aïn Néchéa Fm., specially in the SE section (540-580 m, 610-700 m) as well as in the Kheneg el Aatène Fm. in the intermediate section $(330-380 \mathrm{~m})$. In places, they are intensively bioturbated by Skolithos $(5-100 \mathrm{~cm}$ in length) that may fully obliterate primary sedimentary structures ("piperocks"). The latter facies develop largely to the south, e.g., in the Ahnet area (Banquette unit, see below). In the less bioturbated sandstones, low angle to sigmoidal trough cross-laminated bedsets with reactivation surfaces are preserved (Fig. 5C). Well defined cyclic successions, 3-5 in thickness, may develop in places. Thickening upward cross-laminated bed sets, which are progressively more and more bioturbated upwards (Skolithos, occasional Rusophycus), are truncated by a horizontally to subhorizontally laminated sandstone bed the top of which is burrowed by large Diplocraterion.

The texture, sedimentary structures and bioturbations indicate high-energy nearshore environments. Though most of the Skolithos-generated piperock are classically attributed to storm-dominated nearshores, tidal influences are suggested by frequent tidally-bundled, migrating bedforms (Nio \& Yang 1991). The possibility that Skolithos burrows formed into previously deposited fluvial deposits or in mouth-bar sands cannot be rule out, at least locally. Sandstone beds with horizontal lamination and sparse Diplocraterion reflect episodic higher energy conditions and preservation of subordinate storm-related deposits. The bioturbated sand-flat facies reflects environments located between the shoreline and shoaling areas beyond which sedimentation was storm dominated.
Mixed tidal and shoreface facies association. - Mixed tidal and shoreface deposits are recognised in the Aïn Néchéa Fm. in the NW section, in the upper Foum Zeïdiya Fm. in the three sections (e.g., 1620, 1700, $1790 \mathrm{~m}$ ) and subordinate occurrences are present in the Bou M'haoud Fm. Those deposits form $0.5-10 \mathrm{~m}$ thick sandstone units that constitute the upper part of coarsening- and thickening-upward succession. In places, a poorly developed $(<1 \mathrm{~m})$, thinning-upward trend is observed on top of it. Deposits are dominated by medium-grained, $0.2-1 \mathrm{~m}$ thick sandstone bed, either amalgamated or with intervening siltstones. They show a variety of primary sedimentary structures: isolated HCS and SCS beds; 0.2-0.5 m thick, low-angle tangential to sigmoidal, cross-laminated bed sets grading downward in bioturbated bottomsets and including reactivation surfaces underlain by a thin $(<2 \mathrm{~mm})$ intercalation of fines or abundant 1-3 cm long rip-up clasts; low-angle to horizontally laminated sandstone beds; wave ripples with straight or polygonal crests; two-dimensional to linguloid current ripples. Those facies are moderately bioturbated, with Skolithos as the most common structures. Daedalus structures are relatively abundant in places in the Foum Zeïdiya Fm. (Lessertisseur 1971). Thin-bedded sandstones with pervasive mottling concealing primary sedimentary structures locally form $<1 \mathrm{~m}$ thick intervals. Thinning-upward beds in the topmost part of mixed tidal and shoreface successions are typified by small-scale HCS beds, wave ripples and may contain shell beds mainly made up of disarticulated to fragmented linguliformean brachiopods.

The facies interpretation is based on both the sedimentary structures and the stratigraphic position of these deposits. HCS-bearing facies represent open-marine environments. Sand waves, common Skolithos and Daedalus structures point to high-energy tidal-dominated environments, whereas fully bioturbated facies suggest low-energy restricted-marine environments. The association of open-marine, tidal-dominated and restricted-marine deposits through high-frequency cycles evidenced by the potential preservation of fine-grained sediments is interpreted as the amalgamation of sands deposited on both side of a shoaling area with minor preservation of upper shoreface deposits due to marine erosion. They represent transgressive facies, as supported by the stratigraphic occurrence of the mixed tidal and shoreface facies association on top of underlying storm-dominated facies and below overlying thinning-upward sandstones grading to inner shelf facies.

Figure 4. Sedimentary logs of the NW, intermediate and SE sections. Macrofauna relates to samples collected in February 2005. Location of section in Fig. 2. 
Jean-François Ghienne et al. • The Cambrian-Ordovician succession in the western Algeria

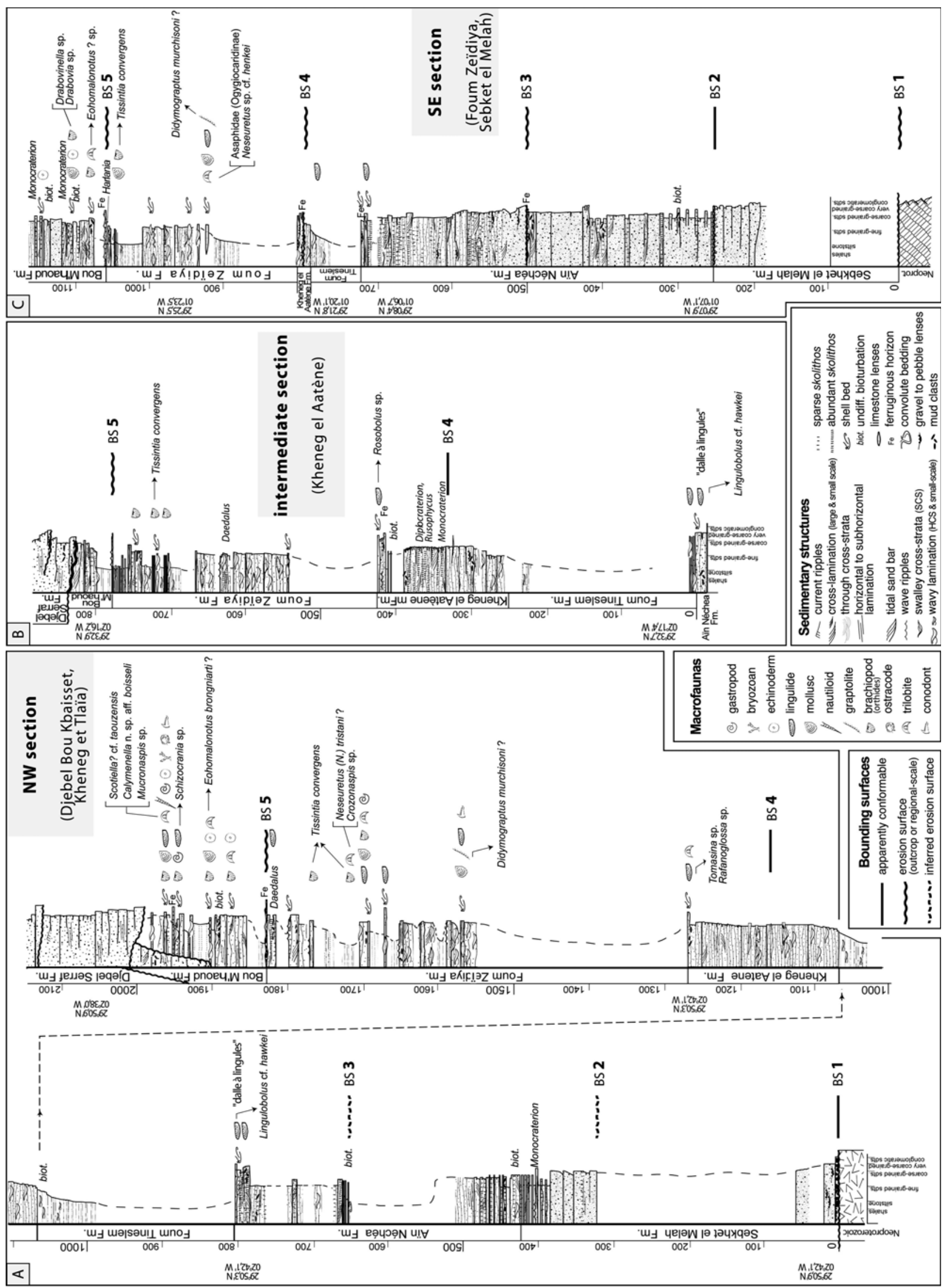


Upper shoreface facies association. - Whereas thin upper shoreface deposits have already been reported within the bioturbated sand-flat facies association, an additional facies association is proposed here to describe fine-, medium- or coarse-grained sandstones that constitute $30 \mathrm{~m}$-thick intervals within in the middle part of the Kheneg el Aatène Fm. in the NW (1170-1200 m) and intermediate (300-325 m) sections. They comprise amalgamated, m-thick, sandstone beds within which horizontal to low-angle laminations prevail. Those laminations locally show 1-4 cm thick, quartz-rich laminae, separated by black, $<1 \mathrm{~mm}$ thick horizons (Fig. 5D). Very coarse-grained lenses and lags of cm-long rip-up clasts have been observed. Isolated, erosion based, cross-bedded sandstone beds are also present, the topmost part of which comprises horizontal laminae truncating the underlying oblique laminae.

The predominance of horizontal to low-angle laminations, in association with thick laminae related to swash processes in the surf zone, the virtual absence of bioturbation and coarse-grained facies suggest a high-energy, most probably non-barred, upper shoreface environment. Cross-bedded sandstones were deposited in relation with longshore or wave-generated cross-shore currents (Clifton 1976).

Storm-dominated shoreface facies associations. - Two types of storm-dominated shoreface sandstones have been identified, an amalgamated and a non-amalgamated type. Amalgamated shoreface sandstones are present in the three sections within the lower part of the Kheneg el Aatène Fm. (NW section, 1060-1010 m) and in the upper part of the Foum Zeïdiya Fm. (1550-1575, 1600-1630 m). Here, the facies association that rest above conspicuous thickening-upward motifs comprising the innershelf facies association, is mainly made up of sorted fine to mediumgrained sandstones. It is typified by large-scale, amalgamated HCS, micaceous sandstone beds, $0.4-0.8 \mathrm{~m}$ in thickness. Undulating laminae are $\sim 2 \mathrm{~m}$ and locally up to $4 \mathrm{~m}$ in wavelength, $0.2-0.5 \mathrm{~m}$ in amplitude. The degree of amalgamation generally increases upwards where HCS beds grade in SCS beds. Bioturbation is virtually absent. Ovoidal, shell-rich limy concretions are frequent. These features, $1-2 \mathrm{~m} \times 0.3-0.6 \mathrm{~m}$, bear siltstone clasts and disarticulated faunas such as linguliformean brachiopods and occasional trilobites, bivalves, gastropods and graptolites.

Non-amalgamated shoreface sandstones have been identified in the uppermost Aïn Néchéa Fm. in the intermediate $(0-10 \mathrm{~m})$ and SE $(720 \mathrm{~m})$ sections, in the uppermost Kheneg el Aatène Fm. in the SE section $(800 \mathrm{~m})$ and in the Bou M'haoud Fm. in the NW section (> 1920 m). HCS beds, $0.2-0.5 \mathrm{~m}$ thick, with occasional wave ripples on top, are separated by siltstone interbeds. They form several metres-thick thinning upward successions. They are locally associated with low-angle laminated coarse-grained sandstones, conglomeratic lenses, or shell beds generally characterised by disarticulated to fragmented lingulids (uppermost Aïn Néchéa Fm.) or fragmented echinoderms (Bou M'haoud Fm.). In the NW section (1940 m), fossil-bearing lenses contain in addition trilobites, brachiopods, bryozoans, ostracodes, chitinozoans and scarce conodonts (Fig. 4).

The predominance of HCS in these sandstones definitely points to shoreface-dominated facies associations (Harms et al. 1982, Brenchley et al. 1986). The size of the HCS in both the amalgamated and non-amalgamated shoreface sandstones reflects high-energy storm-dominated environments, with preservation in respectively amalgamated low accommodation and high accommodation conditions. The former were deposited within longterm coarsening-upward (regressive) trends whereas the latter exhibit fining-upward (transgressive) trends. High accommodation allows wave ripples and fines to be preserved, while low accommodation results in amalgamation of event beds. SCS beds are here interpreted as the result of increasing amalgamation rates resulting in the systematic truncation of hummocks in shallower environments (Dumas \& Arnott 2006). Ovoidal, shell-rich concretions most probably represent the infill by rip currents of storm-generated large-scale gutter casts. Early cementation that results in their pre-compaction ovoidal morphology, was favoured by the dissolution of the carbonate-rich shelly fauna.

Inner-shelffacies association. - The inner-shelf facies association forms thin $(<5 \mathrm{~m}$ ) to thick (up to $250 \mathrm{~m}$ ) successions that are generally poorly exposed. It comprises the whole of the Foum Tineslem Fm. and the lower part of the Foum Zeïdiya Fm. in the three sections. It has been identified in the Aïn Néchéa Fm. only in the topmost part of the soft talus in the NW section $(640 \mathrm{~m})$. This association comprises silty shales, micaceous siltstones and heterolithic facies. Heterolithic facies are fine-grained sandstone beds interstratified with siltstone interbeds. Silty shales and siltstones with rare sandstone beds typify lower and middle parts of inner-shelf succession. In the upper part of the thick inner-shelf successions a conspicuous coarsening- and thickening-upwards trend can be observed with the superimposition of successive 2-4 m thick, coarsening- and thickening-upwards smaller-scale successions. Sandstones initially appear within siltstones as flaser bedding, grading upwards in 1-4 cm thick rippled sandstone wavy beds with persistent orientations in cross-strata dips, followed by the development of 5-20 cm thick HCS beds, firstly lenticular and isolated with occasional wave reworking on top, then tabular and progressively amalgamated. Bioturbation is poorly expressed. Isolated lenticular shell beds with disarticulated brachiopods and scarce trilobites occur in places. 



Figure 5. Sedimentary facies in the Cambrian-Ordovician succession of the Ougarta Range. • A - coarse-grained, cross-bedded sandstones (fluvial facies association; SE section, $450 \mathrm{~m}$ ). $\bullet \mathrm{B}$ - alternating argillaceous fine-grained sandstones and cross-bedded, bioturbated sandstone beds reflecting coastal plain to estuarine conditions (NW section, $655 \mathrm{~m}$ ). $\bullet \mathrm{C}$ - cross-bedded sandstones intensively bioturbated by Skolithos (bioturbated sand-flat facies association; SE section, $660 \mathrm{~m}$ ). $\bullet \mathrm{D}$ - horizontal to low-angle, thick laminations in medium to coarse-grained sandstones (upper shoreface facies association; intermediate section, $310 \mathrm{~m}$ ). $・ \mathrm{E}$ - large-scale hummocky cross-stratification (storm-dominated shoreface facies association; SE section, $780 \mathrm{~m}) \cdot \bullet \mathrm{F}$ - heterolithic deposits alternating siltstones and wavy to current-rippled sandstone beds (inner-shelf facies association; NW section, $1050 \mathrm{~m}$ ).

Flasers and thin sandstone wavy beds characterised by consistent migrations of the foresets suggest distal tempestites deposited by low-density combined flows. Their association with relatively thick HCS beds reflects a storm-dominated inner-shelf. Muddy interbeds reflects post-storm deposition of fine material and/ or fair weather conditions.

Tidal ridges facies association. - The tidal ridges facies association characterises the Bou M'haoud Fm. in the SE section. It comprises $4-10 \mathrm{~m}$ thick, thickening- and coarsening upwards sandstone units showing a variety of facies. Their internal organisation is generally indistinct but two consistent patterns are: (i) erosion-based, 0.1-0.4 m thick, HCS to horizontally laminated beds prevailing in the fine- to medium-grained lower part, in association with wave ripples; (ii) medium to coarse-grained, $0.3-1 \mathrm{~m}$ thick trough-cross-bedded sandstones prevailing in the upper part. Sandstones are well to moderately sorted, even in 


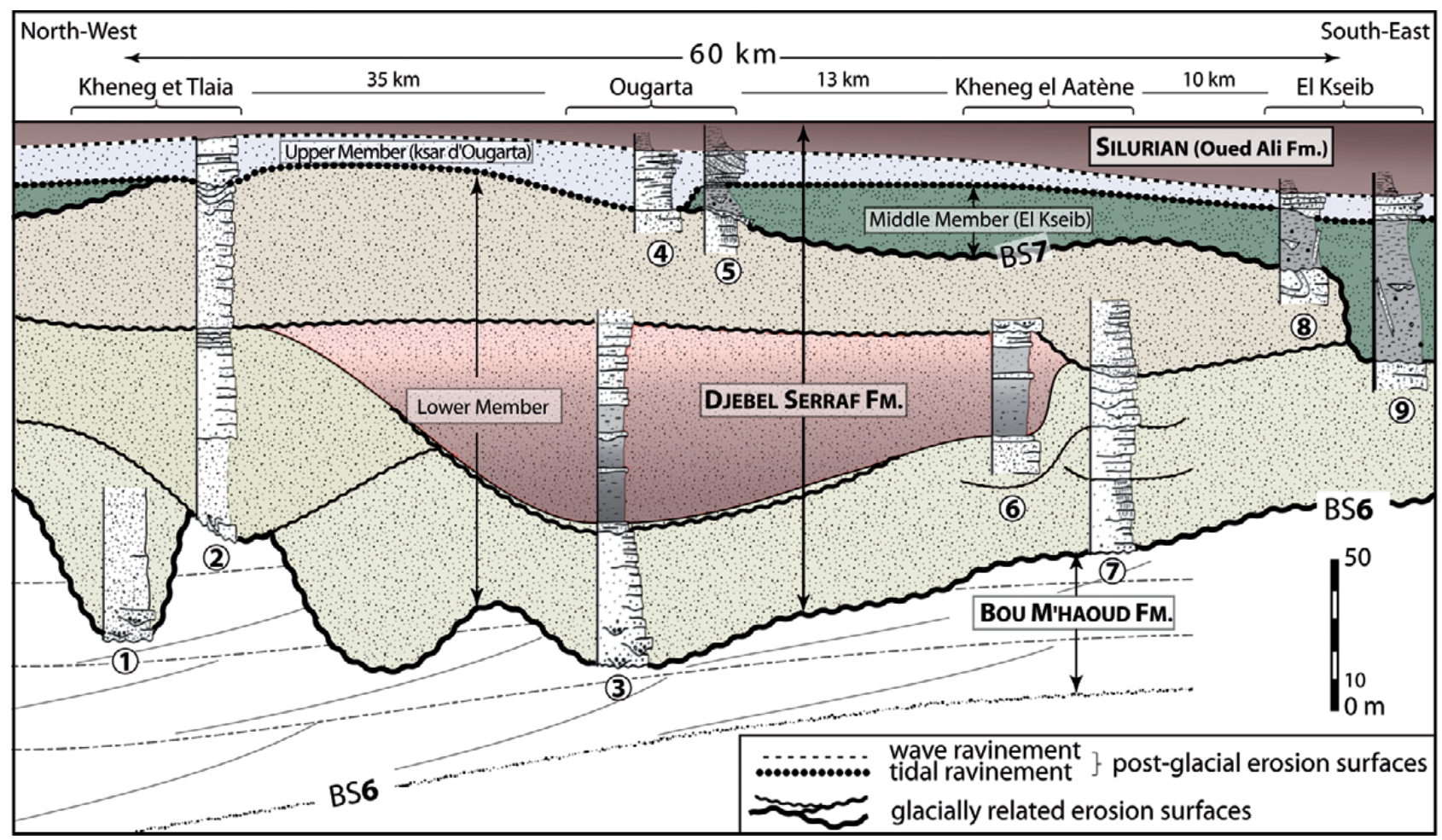

Figure 6. Correlation of nine cross-sections in the Djebel Serraf Fm. (location in Fig. 2), illustrating the internal stratigraphy of the Late Ordovician glacial record in the Ougarta Range, which is characterised by vertically superimposed erosion-based depositional units. See text for further details.

coarse-grained facies. Skolithos and shell beds (echinoderm and brachiopod fragments) are distributed in both facies.

Large-scale foresets, $6 \mathrm{~m}$ in height, have been observed in one outcrop that we have not had the opportunity to examine closely. However, we suggest that the facies patterns described above represent two depositional environments associated with large subtidal sandridges. Deposits in the lower part of the individual units show evidence of reworking either by wave or storm. They formed in inter-ridge areas or correspond to their bottomsets. Trough cross-bedded facies characterise migrating complexes driven by tidal currents. The frequent occurrence of coarse-grained sandstones that are usually absent from the shelf, shoreface or tidal environments may suggest that the tidal ridge facies association is associated with tidal-dominated delta environments.

\section{The glacially related strata}

Uppermost Ordovician, glacially related strata constitute the Djebel Serraf Fm., which is itself subdivided in three members (Arbey 1968, 1971, 1988; Legrand 1988). Deposition in the lower and middle members (the latter also known as the El Kseib Mb.) was influenced by glaciers while the upper member (also known as the Ksar d'Ougarta
Mb.) is made up of post-glacial transgressive facies. The internal stratigraphy of the glacially related strata is rather intricate and only an outline of them is proposed in the following based on a reconstructed, regional-wide geological profile (Fig. 6).

Lower bounding surface. - The lower contact of the glacial deposits is an erosion surface truncating pre-glacial strata. This is a composite surface as internal erosion surfaces may locally cut through the whole of previously deposited glacial strata and amalgamate with older ones (Kheneg et Tlaïa area in Fig. 6). Erosion depth is unknown but a minimum value of $50 \mathrm{~m}$ is estimated, which corresponds to the residual thickness of pre-glacial strata between two adjacent incisions. From the NW towards the SE, the erosion affects progressively older strata. That does not imply more severe erosion toward the SE. A consistent depth of erosion into a Cambrian-Ordovician succession that progressively thin towards the SE would result in similar relationships.

Fluvio-deltaic facies association. - These deposits form the main part of the glacial record and comprise the lower member of the Djebel Serraf Fm. Erosion-based, several tens of metres thick units are laterally juxtaposed or vertically superimposed (Fig. 6). These units, which fill in several kilometres wide, up to $50 \mathrm{~m}$ deep palaeovalleys, are 
made up of crudely stratified coarse-grained to argillaceous fine-grained sandstones. Erosion surfaces are locally underlain by conglomerate deposits (intraformational clasts). Horizontal to subhorizontal laminations are ubiquitous. Current ripples and vertical sheet dewatering structures are subordinate sedimentary structures. These units generally fine and thin upwards but one of those shows a $50 \mathrm{~m}$-thick coarsening and thickening upward succession. Evidence for glacial influences is limited to the occurrence of poorly preserved intraformational glacial striae as described elsewhere in the Late Ordovician record (Deynoux \& Ghienne 2004), and to large-scale (> $50 \mathrm{~m}$ ) folded and subsequently truncated structures that are related to glacial loading processes (Le Heron et al. 2005).

These facies that are characterised by upper-flow regime conditions, and their overall large-scale architecture, characterise flood-dominated, sediment-laden stream-flow sediments deposited in proglacial fluvial environments (Ghienne 2003, Ghienne et al. in press). Delta systems and related coarsening- and thickening-up successions might have formed within glacially eroded and subsequently flooded depressions.

Glaciomarine facies association. - Glaciomarine deposits constitute the middle member (or El Kseib Mb. sensu Legrand 1988) of the Djebel Serraf Fm. It corresponds to rather thin $(<25 \mathrm{~m}$ thick) and lenticular sandy diamictite bodies including lonestones, sandstone dykes $0.1-1 \mathrm{~m}$ in thickness and small sandstone channel structures. Resting on a glacial erosion surface (Arbey 1968), these deposits reflect subaquatic outwash fan deposition (Powell 1990). They are ascribed to glaciomarine rather than glaciolacustrine facies as they bear abundant chitinozoans of Hirnantian age (elongata Biozone, Paris et al. 1995, 2007). Therefore, the glacial erosion surface at the base of this middle member also corresponds to a transgressive surface as it marks an abrupt and definitive change between underlying fluvio-deltaic deposits (lower member) and overlying marine deposits (middle and upper members).

Post-glacial facies association. - Post-glacial deposits comprise the bulk of the upper member of the Djebel Serraf Fm. (or Ksar d'Ougarta Member, sensu Legrand 1988) and constitute a widespread, erosion-based sandsheet that rests unconformably on underlying glacially-related strata (lower and middle Mbs.; Figs 6, 7A). This facies association is made up of medium- to coarse-grained, Skolithosbearing, cross-bedded sandstones organised in large lowangle foresets similar to the tidal ridges facies association described in preglacial strata. Tidal ridges deposits are themselves truncated and overlain by coarse- to very coarse-grained sandstones that bears an abundant macrofauna (brachiopods, trilobites; Legrand 1988) and a few graptolites recalling Normalograptus persculptus
(P. Štorch, written information in 2006). Coarse-grained sandstones then grade upward rapidly in less than $2 \mathrm{~m}$ in wavy heterolithic fine-grained sandstone beds and then siltstones and black shales, uppermost Ordovician and then lowermost Silurian in age.

These deposits are ascribed to a post-glacial transgressive wedge, initially developed in tidal environments devoid of glacial influences and related to post-glacial transgressive processes that lag the underlying coarsegrained glacially-related strata as proposed by Beuf et al. (1971) around the Tuareg Shield (e.g., Ahnet area). Tidal deposits are themselves truncated by a wave ravinement surface sealed by shoreface to inner-shelf environments (Fig. 7A, B).

\section{Sequence stratigraphic interpretation of the pre-glacial succession}

The three sections present a conspicuous cyclic pattern that is well expressed in the NW section (Fig. 4). Here, up to $300 \mathrm{~m}$ thick fine-grained intervals highlight four 200-400 m thick sandstone units that progressively coarsen and then rapidly fine upward (Fig. 3). Sandstone units form geomorphological markers that can be correlated throughout the Ougarta Range. Six depositional sequences and associated bounding surfaces have been identified (Figs 4, 8). Bounding surfaces generally depart from lithostratigraphic boundaries but depositional cycles correspond mostly to the regional stages described by Legrand \& Nabos (1962) and Legrand (1985). Higher frequency units are also recognizable.

\section{Depositional units in the Ougarta Range}

Three orders of depositional units have been delineated (Fig. 8). From the thicker to the thinner, they are: (i) depositional sequences; (ii) short-term sequences; (iii) genetic units.

Genetic units are 3-20 $\mathrm{m}$ in thickness, in places up to $50 \mathrm{~m}$. Although further work is needed to ascertain their spatial continuity, the genetic units can apparently be correlated from the SE to the NW sections, at least those constituting the Foum Zeïdiya Fm. (Fig. 3D). They appear most often as coarsening and thickening upward assemblages, with a thin or absent fining and thinning interval in their uppermost part. No mappable erosion surface can be identified and they can be regarded as bounded by high-frequency maximum flooding surfaces. At smaller scale, genetic units internally comprise very high frequency cycles that are under the resolution of the sedimentary logs used in this paper. It is speculated that these smaller-scale units cannot be correlated over long distances as they should rep- 

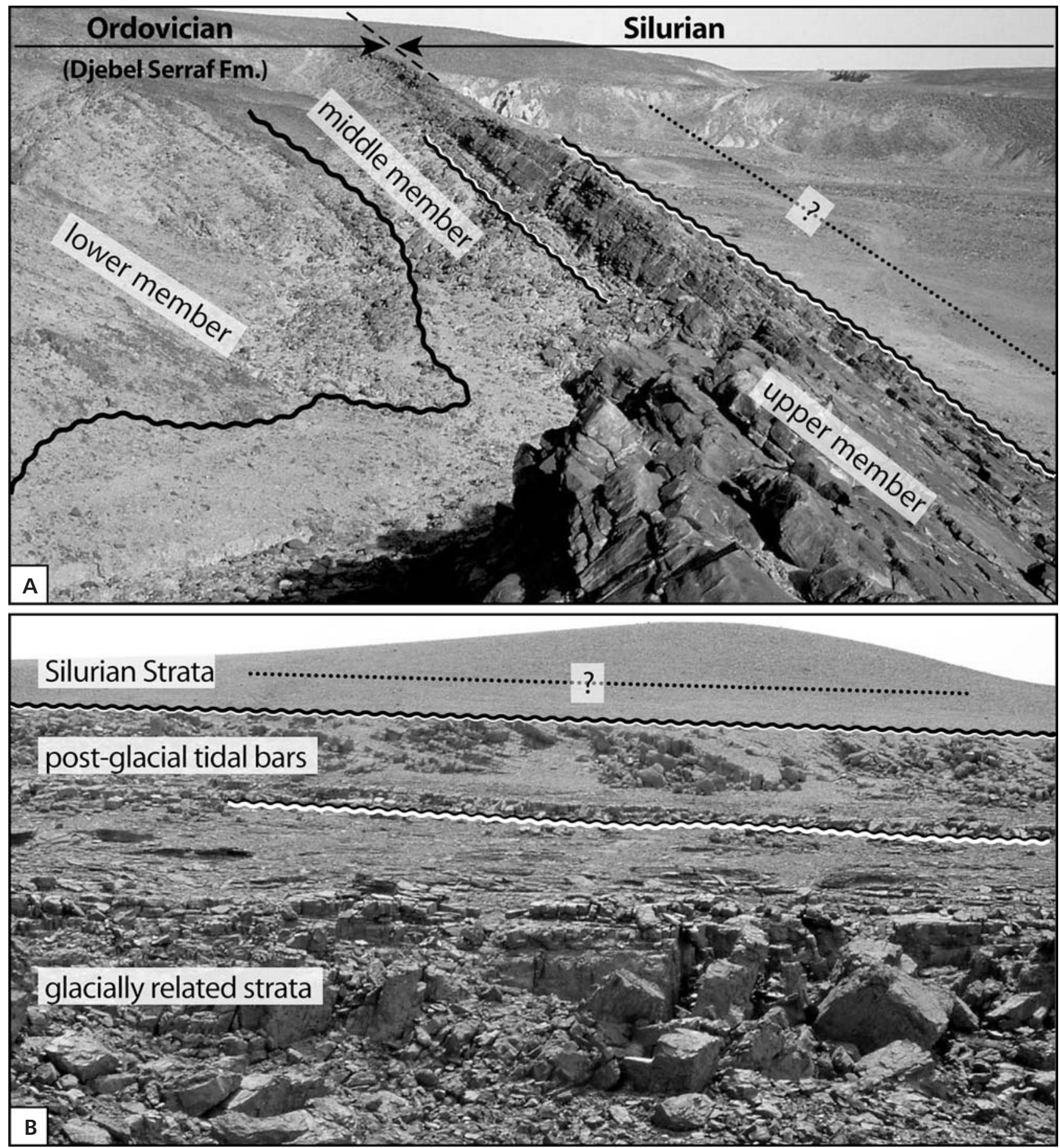

Figure 7. Stratigraphic relationship between glacially-related and post-glacial strata. Tidal deposits are bounded at their base and at their top by transgressive ravinement surfaces. • A - Ougarta Range (north to the Ksar d'Ougarta). B - Ahnet area (Idjerrane High, southern Algeria).

resent the shoreface/ inner-shelf clinoforms that might not have exceeded $\sim 10 \mathrm{~km}$ in length (e.g., Hampson 2000).

Successive genetic units usually display consistent trends in thickness variations and facies composition. The stacking pattern of genetic units is then used to define informal short-term sequences that correspond to 100-200 m thick depositional units, the associated bounding surfaces of which are generally poorly defined (Fig. 3D, E). This approach is straightforward in the thick and well developed shallowing-upward portion of the depositional sequences, but less easy in the rather condensed deepening-upward portion of the depositional sequences. Short-term sequences are units, which can be correlated at least at the scale of the Ougarta Range and are also potentially useful 
for long-range correlation. A short-term sequence may comprise a retrogradational and then progradational suite of genetic units. One of the two trends generally prevails and entirely retrogradational or progradational are also identified. In sand-dominated successions within which genetic units have not been properly logged (e.g., Aïn Néchéa Fm. in the SE section), short-term sequence delineation is based on consistent basinward or landward shift of depositional facies.

Depositional sequences are 300-700 m thick units, the extent of which largely exceeds the Ougarta Range extending over the whole of the North African Platform and on its extension on the Arabian Plate (Sharland et al. 2001, 2004). Six depositional sequences have been distinguished (Figs 3, 8, 9) that are described in the following. They include several short-term sequences that are made up of a suite of genetic units. The delineation of depositional sequences is based on the recognition of transgressive and regressive trends. They then correspond to Transgressive-Regressive (T-R) sequences (Embry 1995, Catuneanu 2002) bounded by transgressive surfaces (or surfaces of maximum regression). T-R sequences predominate due to: (i) the overall shallow-marine setting within which highstand- and lowstand-system tracts are poorly differentiated; (ii) major maximum flooding surfaces virtually unidentifiable at outcrop as they are most often scree-covered; and (iii) the occurrence of significant transgressive erosion surfaces. T-R depositional sequences comprise an underlying transgressive system tract and an overlying regressive system tract (Fig. 8). The transgressive system tract of T-R depositional sequences comprises a lower, sand-dominated succession overlain by an upper, rapidly fining-up succession. The maximum flooding surface that ideally bound the transgressive and regressive system tracts has never been properly identified at outcrop as it is located within the poorly exposed soft talus of offshore facies (e.g., Fig. 3C). The regressive system tracts are poorly expressed within Cambrian strata. In the Ordovician they consist generally in a thick coarsening-up succession, comprising shale-dominated sediments at the base and grading upwards in sand-dominated sediments (e.g., Fig. 3B, D). They display progressively upwards more and more proximal short-term sequences. In some case, an additional stratigraphic surface can be identified that subdivides the regressive system tract into two packages assimilated as an underlying highstand and overlying lowstand wedges. Examples of correlative surfaces of a subaerial unconformity (end of sea level fall, $c f$. depositional sequence 4) and basal surfaces of forced regression (onset of sea level fall, $c f$. depositional sequence 5) have been evidenced in places.

In the following, depositional sequences identified in the Ougarta Range (Fig. 8) are described separately and integrated into a stratigraphic scheme at the platform scale through a correlation with the synthetic, Cambrian-
Ordovician, basinward succession of the Anti-Atlas, and a coeval upstreamward succession fringing the Tuareg shield (Ahnet areas; Fig. 10). This correlation that is based both on the literature and on recently acquired field (Anti-Atlas, Ahnet) and biostratigraphic (Ougarta, AMg-1 well, $c f$. Fig. 9) data illustrates an almost $1000 \mathrm{~km}$ long depositional profile.

\section{Depositional sequence 1: "Lower" Cambrian}

Ougarta Range. - This sequence of fluvial deposits has not been studied in detail; its lower bounding surface (BS1) truncates the basement rocks. In the NW section, the Cambrian-Ordovician strata rest with an apparent conformity on rhyodacitic tuffs and lavas. The contact is underlain by a discontinuous, 0 to $0.2 \mathrm{~m}$ thick conglomerate bed overlain by a fining-upwards, arkosic, very-coarse to coarsegrained, cross-bedded sandstones. To the SW, BS1 cut through a $>4 \mathrm{~km}$ thick, steeply dipping folded succession of sandstones and volcanics (Fig. 2; Caby 1996). Conglomerates that contain fluvially reworked wind-shaped pebbles (dreikanters) have been documented (Arbey \& Caby 1966).

The upper bounding surface (BS2) of depositional sequence 1 in the SE section separates the Sebkhet el Melah and Aïn Néchéa formations. A noticeable lithologic break is observed between underlying grey arkoses and overlying red arkosic sandstones. In addition, a prominent metrethick silicification affects the topmost deposits. BS2 has not been observed in the NW section and so it is arbitrarily placed below arkosic sandstones that here constitute the upper part of the Sebkhet el Melah Fm., above a broadly fining-up succession of poorly outcropping fluvial deposits corresponding to the lower two-thirds of the formation.

Regional correlation. - The lower bounding surface of the Cambrian-Ordovician succession (BS1 in the Ougarta) corresponds to the major erosional unconformity that seals the Pan-African deformation. It is recognised around the Tuareg shield, where it is called the infra-Tassilian surface (Beuf et al. 1971, Fabre 2005) and truncates all the deformed, more or less metamorphosed Neoproterozoic to basal Cambrian rocks (sedimentary strata, volcanics, basement rocks) related to the Pan-African Orogeny and post-collisional collapse/strike-slip basins (Fig. 2). In outcrop, this is a flat surface but palaeorelief forms are known in places. This surface corresponds to a major fluvio-eolian by-pass (Beuf et al. 1971, Eschard et al. 2005) associated with a stratigraphic hiatus, increasing progressively from north to south. It is topped by marine uppermost Neoproterozoic "Lower" Cambrian strata in Morocco (Destombes et al. 1985), whereas it is overlain by younger strata of "Upper"(?) Cambrian or Ordovician age in the Hoggar. Coeval intra-continental depositional systems have developed lo- 
cally. The arkoses of the Sebkhet el Melah Fm., present in the whole of the Ougarta or in depocentres such as this related to the up to $1 \mathrm{~km}$-thick Ben Tadjine conglomerates in southwestern Ougarta, are considered to be time-equivalent with processes that resulted in the infra-Tassilian surface to the south (Fabre et al. 1988). Hence, this depositional sequence is not present in the Ahnet area though coeval deposition might have been preserved in places (e.g., Al Moungar conglomerates in the Tassili areas; Beuf et al. 1971, Fabre \& Kazi-Tani 2005).

This depositional sequence most probably represents in the Ougarta a late transgressive to early highstand deposition. To the north, in the Anti-Atlas, the coeval succession would correspond to the uppermost part of the Western Anti-Atlas Group. However, the transgressive system tract is here fully developed including a thick carbonate-dominated succession (Upper Limestone Fm.). The lower Terminal Sandstones Fm. corresponds to the upper part of the regressive system tract (Landing et al. 2006).

\section{Depositional sequence 2: "Middle" Cambrian}

Ougarta Range. - The lithologic break and associated silicification possibly of pedogenetic origin (e.g., Álvaro et al. 2003a) suggest that BS2 represents a stratigraphic hiatus across which sediment source and palaeoenvironments changed significantly. The second depositional sequence mainly comprises a transgressive system tract and an overlying subordinate regressive system tract. It seals BS2, which is interpreted as the amalgamation of a subaerial erosion surface with a transgressive surface.

The transgressive system tract is particularly well expressed in the NW section where a thick deepeningupward succession of fluvial to shallow-marine deposits is recorded (NW section, 300-550 m). In the SE section, marine influences develop progressively upward within an otherwise fluvial-dominated succession. The regressive system tract that has not been properly characterised is represented by fine-grained deposits in the NW section and by an uninterrupted, $80 \mathrm{~m}$ thick, fluvial unit in the SE section (Fig. 3A). The upper bounding surface (BS3) involves a subaerial erosion surface. It truncates underlying marine deposits and is overlain by estuarine deposits in the NW section while in the SE section, it is an undulating erosional surface with 1-2 $\mathrm{m}$ high palaeorelief forms underlain by a ferruginous granule lag including subangular quartz gravels.
Regional correlation. - The transgressive system tract of depositional sequence 2 correlates to the north with the lower "Middle" Cambrian transgressive strata constituting the upper part of the Terminal Sandstones (Tatelt Fm. of Landing et al. 2006; Fig. 10). In other part of the North Gondwana domain, deposition of carbonate successions, either thick as in Turkey (e.g., Dean \& Monod 1990, Dean 2005) or rather condensed as in Sardinia (e.g., Pillola et al. 1998) is coeval with this worldwide transgression. This transgressive event marks the onset of the flooding of the continental platform in the Ougarta Range, which will occur only later to the south where BS2 should merge with BS1 to form together the Infra-Tassilian surface (e.g., in the Ahnet area). On the Arabian Plate, the related maximum flooding surface most probably correlates to the Cm20 maximum flooding surface of Sharland et al. (2001).

The regressive system tract correlates with the largescale progradation constituting the Internal Feijas Group overlain by the basal Tabanite Group of Destombes et al. (1985). It is suggested that BS3 in the Ougarta acted as a bypass surface, which fed in clastics the main part of the progradation to the north. Early regressive deposits of this sequence may have a time-equivalent fluvial counterpart to the south within the Ajjers Fm. of Beuf et al. (1971).

\section{Depositional sequence 3: upper "Middle" Cambrian-"Upper" Cambrian?}

Ougarta Range. - The third depositional sequence in the Ougarta is limited to a transgressive system tract constituting the upper half of the Aïn Néchéa Fm. In the SE section, it comprises a fining-up succession made up of red, subarkosic, unsorted, coarse- to very coarse-grained cross-bedded fluvial sandstones grading upward into white, quartz-rich sandstones of the bioturbated sand flat facies association characterised by the development of abundant Skolithos burrows (Fig. 8). To the NW, thin estuarine deposits underline a poorly differentiated $150 \mathrm{~m}$-thick shallow-marine quartz-rich sandstones dominated by the mixed tidal and shoreface facies association. It correlates with sandstones, upper "Middle" Cambrian in age (Vecoli et al. 2007), which share a similar transgressive trend in the AMg-1 well (Fig. 9). A significant granulometric break is then used to locate the upper bounding surface of the sequence (BS4) that most probably corresponds to a tidal ravinement surface (see below). As in the AMg-1 well, the "Upper" Cambrian is most probably absent.

Figure 8. Facies and sequence stratigraphic interpretations in the Cambrian-Ordovician succession of the Ougarta Range. Key for sedimentary structures in Fig. 4. Delineation of Transgressive-Regressive depositional sequence is based on the recognition of transgressive surfaces. The latter merge in places with erosional surfaces. In a few cases (sequences 4,5 ), the regressive system tract has been further informally subdivided based on the recognition of an internal stratigraphic surface (respectively, a correlative surface of a subaerial unconformity, and a basal surface of forced regression). 
Jean-François Ghienne et al. • The Cambrian-Ordovician succession in the western Algeria

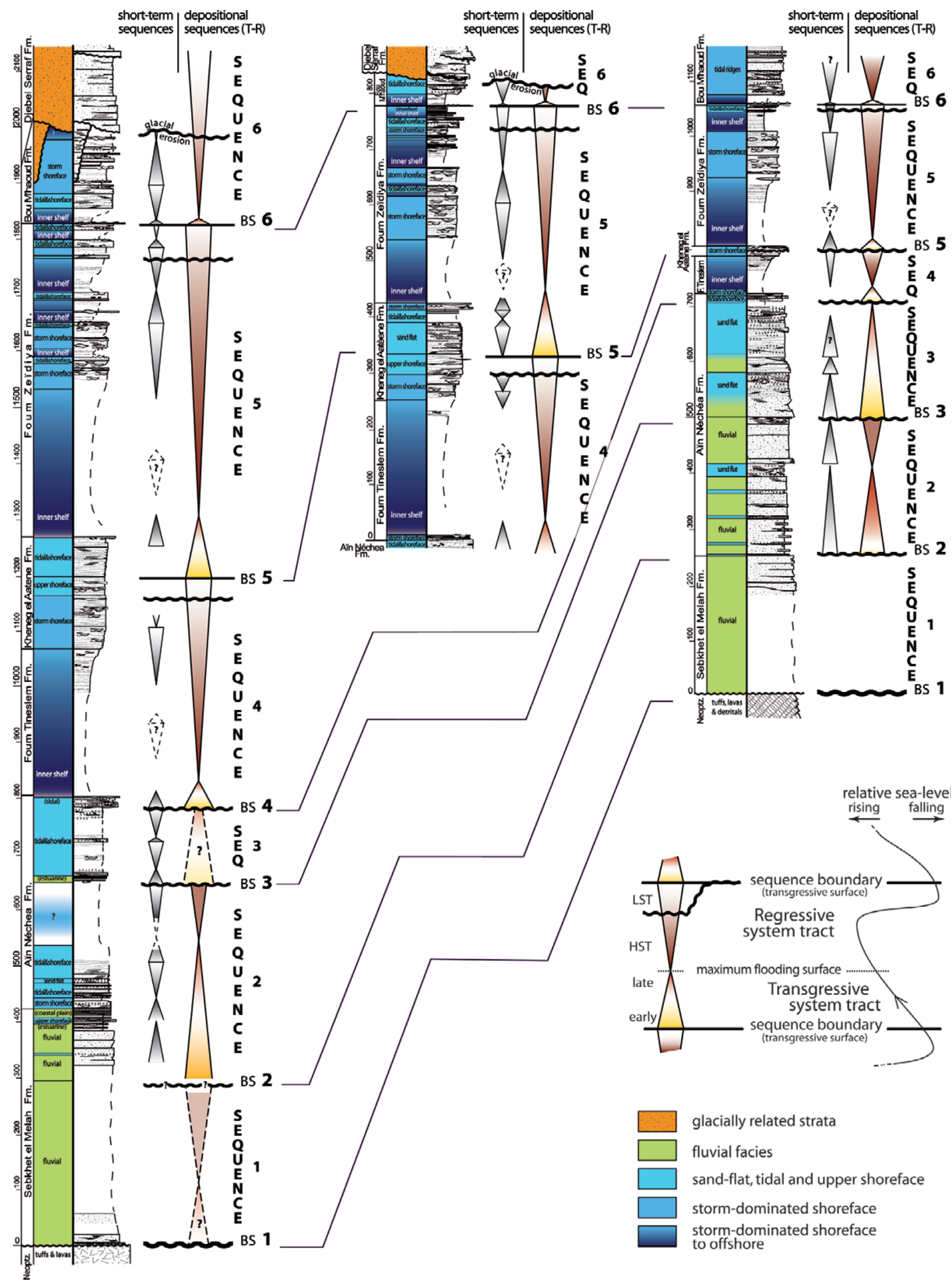


Regional correlation. - Strata coeval of the depositional sequence 3 biostratigraphically correlates to the Anti-Atlas with those constituting the middle to upper part of the Tabanite Group (Fig. 10). In the Central Anti-Atlas, i.e. in the axis of the Cambrian depocentre (Destombes et al. 1985), a 30 m-thick Skolithos-bearing sandstone unit is overlain by a 50-m thick succession dominated by offshore shales. These strata may represent respectively a transgressive system tract overlain by the lower part of a regressive assemblage. The later strata, "Upper" Cambrian in age (Destombes \& Feist 1987), are truncated by coarse-grained sandstones underlining the Ordovician rocks. The absence (Ougarta) or poor development (Anti-Atlas) of the regressive system tract reflect uplift and subsequent erosion related to a poorly constrained "Upper" Cambrian tectonic event, which is identified in Morocco (Destombes et al. 1985, Destombes \& Feist 1987, Burkhard et al. 2006), and in some places in Algeria (Legrand 1985, Crossley \& McDougall 1998) and that may reflect distensive deformation affecting the continental margin further north (Ledru et al. 1994, Álvaro et al. 2003b). "Upper" Cambrian strata, however, were developed more largely farther to the east in other subsiding troughs of the North African platform (Albani et al. 1991, Vecoli et al. 1995, Vecoli 1999). On the Arabian Plate, the related maximum flooding surface most probably correlates to the $\mathrm{Cm} 30$ maximum flooding surface of Sharland et al. (2001). It is also suggested that depositional sequence 3 should be mostly represented to the south around the Tuareg Shield constituting the main part of the Ajjers Fm. of Beuf et al. (1971; equal to the Tin Taradjelli unit in the central Tassili type section of Eschard $e t$ al. 2005), an area which has not been affected by deformation at the continental margin.

\section{Depositional sequence 4: Lower Ordovician}

Ougarta Range. - The fourth depositional sequence comprises a thin, rapidly fining-upward transgressive system tract and an overlying rather thick regressive system tract. Its lower bounding surface (BS4) corresponding to a major granulometric break is sealed by a coarse-grained sand- stone horizon forming the uppermost part of the Aïn Néchéa Fm. (e.g., NW section, 790-800 m). It shows successively: (i) low-angle laminated to cross-bedded sandstones with Skolithos and disseminated fragments of linguliformean brachiopods; (ii) a sharp erosional contact overlain by several sandstone beds containing intraformational clasts and abundant disarticulated, non fragmented linguliformean brachiopods; (iii) in places, as in the NW section (795 m), a single $30 \mathrm{~cm}$-thick shell-bed, observed at the very top of the Aïn Néchéa Fm. constituting a regional marker level (Gomez Silva et al. 1963, Legrand 1985), which laterally evolves into a several metre thick succession of unamalgamated sandstone beds of the stormdominated shoreface facies association (e.g., intermediate section, 0-10 m); (iv) argillaceous and glauconitic deposits constituting the base of the Foum Tineslem Fm. The lower bounding surface and overlying deposits are interpreted respectively as a tidal ravinement surface and tidal deposits. The later are truncated by a wave ravinement surface, and then, overlain by shoreface to inner-shelf deposits forming the lower Foum Tineslem Fm. This association points to a major transgressive event within the Cambrian-Ordovician succession formerly recognised by Legrand (1985). It is lower Tremadocian in age as dated by graptolites (Legrand 1966).

The regressive system tract comprises an up to $400 \mathrm{~m}$ thick, well defined coarsening- and thickening-upward succession of inner-shelf to shoreface deposits constituting the upper Foum Tineslem Fm. and the lower part of the Kheneg el Aatène Fm. (Fig. 3B). The thickness of the regressive system tract notably decreases to the SE where it is represented by a less than $100 \mathrm{~m}$ thick succession, even disappearing totally to the south (Gomez Silva et al. 1963, Legrand 1985, ORGM 2000; Fig. 8). It should be noted that this thin succession is not the result of erosion as it comprises a similar succession ending with stormdominated shoreface deposit, which indicates condensed sedimentation (bypass) rather than post-depositional truncation.

The upper bounding surface of depositional sequence 4 has been placed in the NW section at the boundary between underlying reddish, subarkosic and micaceous shoreface

Figure 9. Dating of the Cambrian-Ordovician succession in the Ougarta Range. On the left, lithostratigraphic column and stratigraphic attributions based on macrofaunas for the Ordovician and on lithostratigraphic correlation with the Anti-Atlas for the Cambrian, according to Legrand (1985 and references therein). In the centre, new data used in this study: newly sampled macrofaunas for the Upper Ordovician (details in Fig. 4); chitinozoan distribution from the AMg-1 well (200 km NE of the Ougarta Range, $c f$. Fig. 1) for the Middle and Lower Ordovician (Paris et al. 2007); acritarch distribution from the AMg-1 borehole for the lowermost Ordovician and Cambrian (Vecoli et al. 2007). On the right, revised age attributions, correlation with global series (Webby et al. 2004 for the Ordovician), subdivision in seven transgressive-regressive depositional sequences as discussed in the text and illustrated in Fig. 8 and proposed correlation with the Sharland et al. $(2001,2004)$ chronostratigraphic charts using codes for maximum flooding surface on the Arabian Plate. Note that the definition of the Lower/Middle Ordovician boundary has changed since Legrand (1985; $c f$. Webby et al. 2004). The lower part of the Foum Tineslem Fm. has been attributed to the Tremadocian based on the recovery of a graptolite fauna (Legrand 1966) although the classical Tremadocian chitinozoan biozones have not been identified in well AMg-1. The upper Katian (lower Ashgill) is now formally identified in the Ougarta Range. 
Jean-François Ghienne et al. • The Cambrian-Ordovician succession in the western Algeria

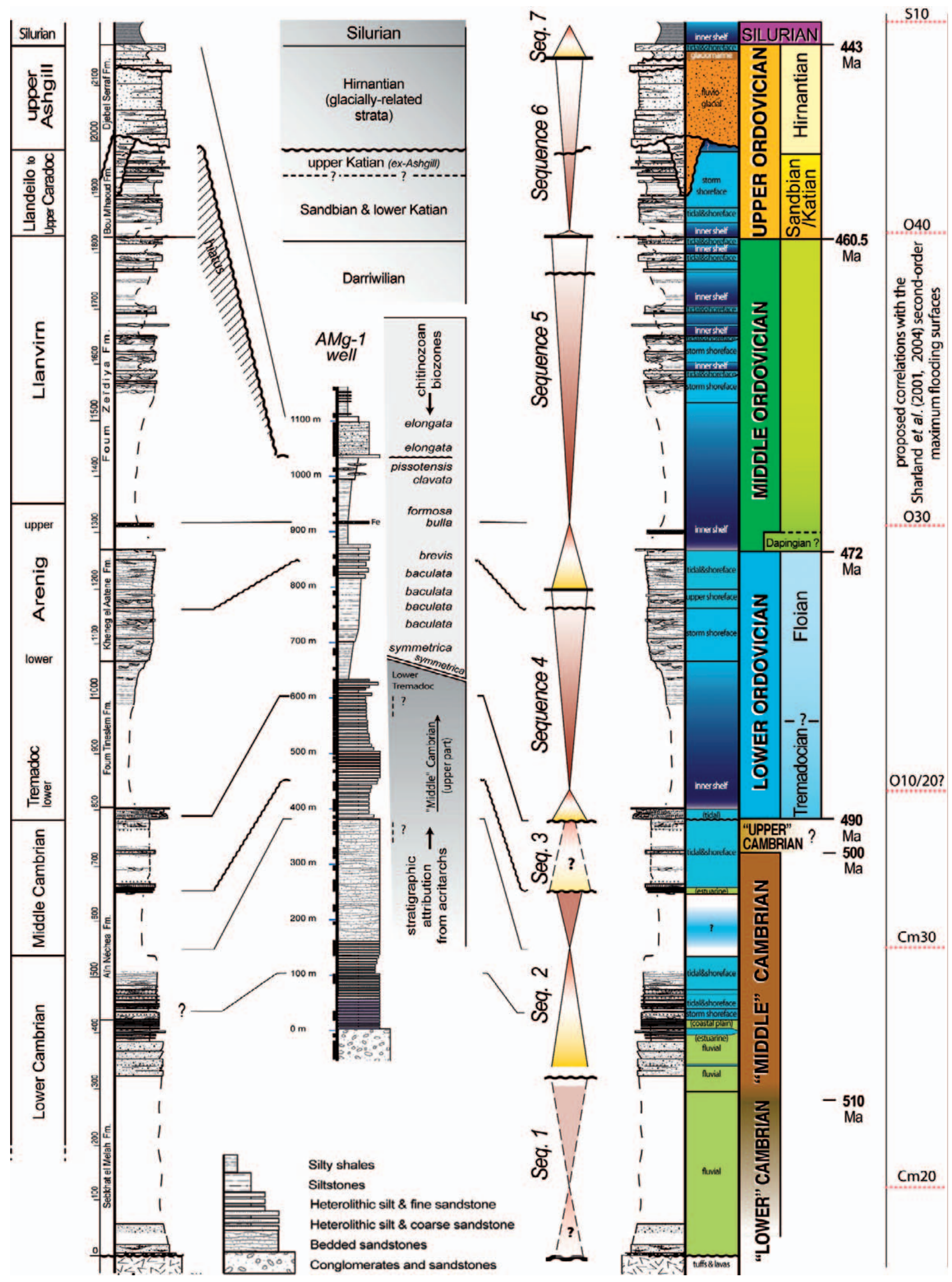


sandstones and overlying white quartzitic tidal and shoreface sandstones. The occurrence of a ferruginous, conglomeratic and oolitic horizon that is reported in the literature within the Kheneg el Aatène Fm. (Gomez Silva et al. 1963, Fekirine \& Abdallah 1998) is used to tentatively differentiate the correlative surface of a subaerial unconformity (Fig. 8). In the SE section, a thin $(<10 \mathrm{~cm})$ conglomerate bed underlines a well defined truncation surface. Here the transgressive bounding surface is therefore superimposed onto a truncation surface. In the absence of fluvial deposits that might have been reworked during subsequent transgression, subaerial erosional processes cannot be ascertained. High frequency regressive and transgressive marine ravinement processes might have occurred with no emersion.

Regional correlation. - The transgressive system tract of the fourth depositional sequence is time-equivalent with an up to $100 \mathrm{~m}$-thick argillaceous succession in the Anti-Atlas (lower Lower Fezouata shales; Fig. 10). To the south, the transgressive system tract finds a parallel with the uppermost part of the Ajjers Fm., especially where it comprises a fluvial-estuarine-sand flat succession (e.g., the central Tassili type section, Eschard et al. 2005). On the Arabian Plate, Sharland et al. (2001) have identified two, Lower Ordovician, maximum flooding surfaces $(\mathrm{O} 10, \mathrm{O} 20)$ that have not been distinguished from the Ougarta record. Either amalgamation may have occurred or one of these two events is less significant and only related to a short-term sequence. However, both events seem to be represented in the Anti-Atlas (Destombes et al. 1985).

Regressive deposits correspond in the Anti-Atlas to a thick succession including the upper Lower Fezouata shales (upper Tremadocian) and the Upper Fezouata shales (Floian, or lower Arenig) of Destombes et al. (1985) while to the south, they are either absent (e.g., the Ahnet section, Fig. 10) or poorly developed. If present, they correspond to a thin prograding succession (unit of the Vire du Mouflon of Eschard et al. 2005). In subsurface of Algeria, the regressive system tract comprises the El Gassi shales and El Atchane sandstones (Fekirine \& Abdallah 1998).

A time-equivalent erosional truncation, similar to the BS 4 in southeastern Ougarta, has also been identified in other places on the platform, e.g., in the N1-2 borehole with superimposed Lower and Middle Ordovician marine shales and no intervening evidence for fluvial deposition (Oulebsir \& Paris 1995).

\section{Depositional sequence 5: upper Lower Ordovician-Middle Ordovician}

Ougarta Range. - Above bounding surface 5, the fifth depositional sequence comprises a transgressive system tract that progressively developed to the north where it corresponds the upper Kheneg el Aatène and lower Foum Zeïdiya fms. The subsequent regressive system tract constitutes the middle and upper Foum Zeïdiya Fm.

At its base, the transgressive system tract comprises relatively thick $(60 \mathrm{~m})$ deposits of the tidal and shoreface facies association (Fig. 3B). They are overlain by several sandstone beds containing intraformational clasts and abundant disarticulated, non fragmented linguliformean brachiopods similar to those of the basal part of depositional sequence 4. An overlying short-term sequence is capped by an oolitic ironstone horizon also including linguliformean brachiopods. This short-term sequence includes upper Arenig (lower Middle Ordovician, i.e. Dapingian) graptolites (Legrand 1964) and time-equivalent chitinozoans (bulla Biozone) are found within the ironstone horizon in the AMg-1 well (Benoît \& Taugourdeau 1961). To the south, the transgressive system tract is limited to several, unamalgamated beds of the storm-dominated shoreface facies association here including conglomerate lenses.

The regressive system tract includes a well defined coarsening-upward succession of short-term sequences with alternating inner shelf and storm shoreface or tidal and shoreface facies associations (Fig. 3D). An abundant macrofauna designates this interval as an essentially Darriwilian succession (Figs 4, 9). The upper bounding surface corresponds to an erosional surface sealed with transgressive lag deposits (see below). However, some metres or tens of metres beneath the sequence boundary, an abrupt contact has been systematically noted that superimposes tidal or shoreface onto underlying inner shelf deposits (Fig. 8). This stratigraphic surface is tentatively interpreted as reflecting the onset of a major sea-level fall (as the basal surface) with overlying strata featuring a lowstand system tract.

Regional correlation. - The sand-dominated transgressive strata are correlated to the north with Floian strata (middle Arenig) of the Zini Sandstones in the western Anti-Atlas (Destombes et al. 1985) and with the Armorican Sandstone in Brittany (Paris 1990). Palynomorphs in adjacent areas (Oulebsir \& Paris 1995) and in the AMg-1 well (Benoît

Figure 10. Regional correlation illustrating depositional sequence development to the north (Anti-Atlas, Morocco) and to the south (Ahnet, southern Algeria) of the Ougarta Range. The progressive disappearance of the fluvial facies through time, the thinning of the successive transgressive system tracts and the development of repetitive open marine conditions designate together the Cambrian to Ordovician succession as a first-order transgressive wedge in North Africa. 


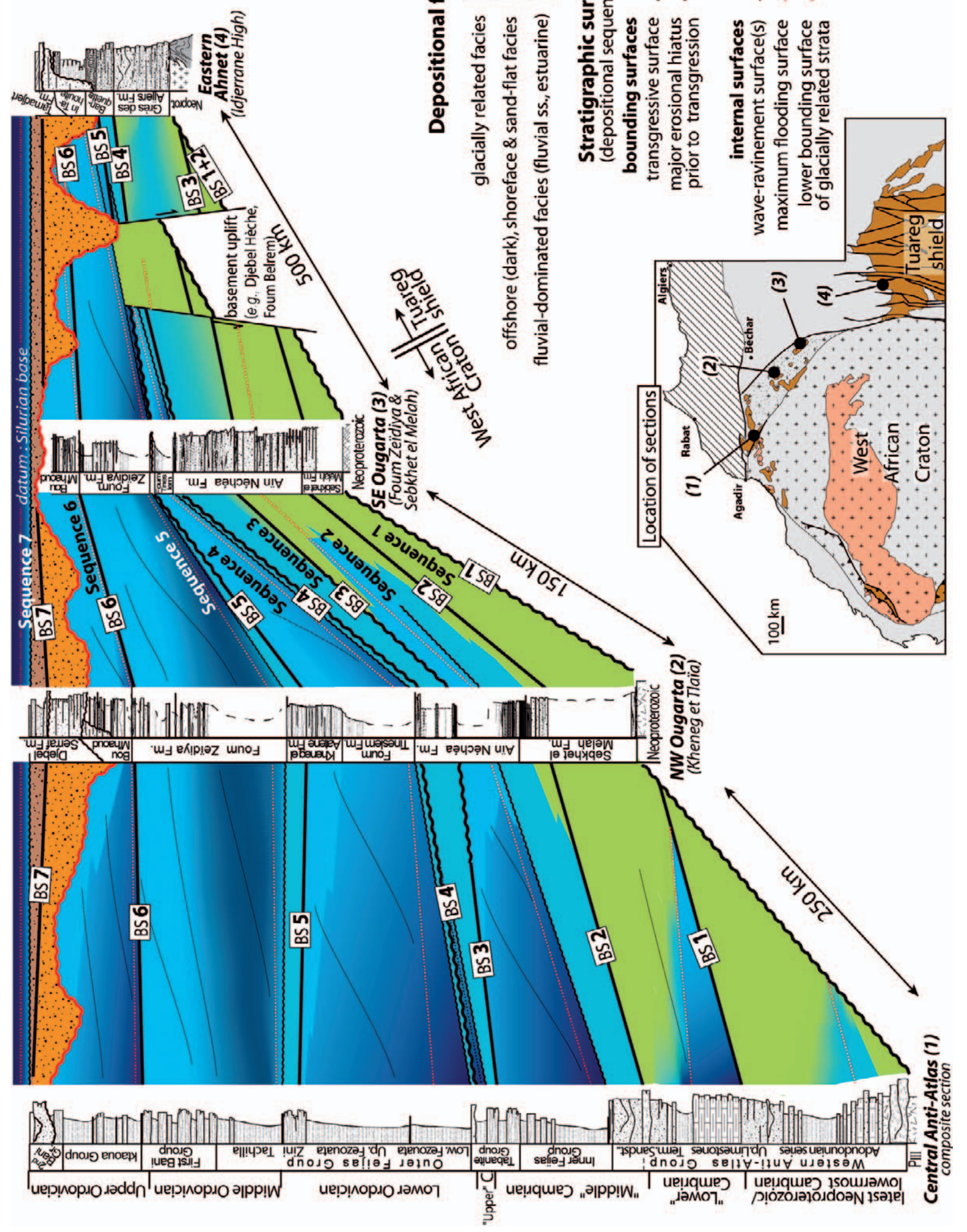


\& Taugourdeau 1961) show that the transgression began as early as the upper Floian (middle Arenig, brevis event of Paris et al. 2007) with another pulsation in the lowermost Darriwilian (uppermost Arenig, bulla event of Paris et al. 2007). This two-fold transgression is tentatively considered as parallel to the two short-term sequences identified in the Ougarta (intermediate section, 330-400 m), with severe condensation of deposits occurring during the Dapingian (upper Arenig), e.g., in Brittany (Dabard et al. 2007) and illustrating in the Ougarta by shell beds and associated ironstones. Maximum flooding conditions occurred slightly later during the early Darriwilian and correspond to the formosa event of Paris et al. (2007). On the Arabian Plate, the related maximum flooding surface correlates to the O30 maximum flooding surface of Sharland et al. (2001).

To the south, the basal transgressive system tract forms a regionally widespread sandstone sheet known in subsurface as the Hamra Quartzites, or the Banquette unit in the Tassili, comprising mainly sand-flat Skolithos-rich deposits (Fig. 10). In places, this unit onlaps onto basement rocks (Beuf et al. 1971). In the Ahnet, tidal deposits comprise the maximum flooding thought more largely open marine conditions might have occurred coevally in more subsiding areas such as in the Tassili (Eschard et al. 2005).

Further south, regressive strata form mainly the shoreface-dominated In Tahouite Fm. (e.g., Eschard et al. 2005). The regressive system tract correlates to the north with the Tachilla shales grading upwards into the sandstones of the First Bani Group (Destombes et al. 1985) of late Darriwilian age. If the identification of a basal sea-level fall surface in uppermost depositional sequence 5 is correct, the overlying strata can be considered as time-equivalent at least with the lower part of the First Bani Group. Strata of the upper First Bani Group, Late Darriwillian to early Sandbian, might represent late lowstand conditions not represented in the more proximal Ougarta Range.

\section{Depositional sequence 6: Upper Ordovician}

Ougarta Range. - The bounding surface 5 corresponds to the base of the Bou M'haoud Fm. (Gomez Silva et al. 1963). This flat surface is sharp at the outcrop scale (Fig. 11A) and erosional at the regional scale. To the south, it rests on progressively older and older genetic units of the underlying Foum Zeïdiya Fm. (compare Figs 4A-C). The erosion surface is underlain by ferruginous, coarse-grained to conglomeratic sandstones with occasional Skolithos. Sandstones are characterised by: (i) the occurrence of intraformational, rounded pebbles $3-25 \mathrm{~cm}$ in diameter (Fig. 11B); (ii) gravely, $40 \mathrm{~cm}$-high asymmetric megarip- ples, $2.5 \mathrm{~m}$ in wavelength with pebble concentrations in their troughs (Fig. 11C); (iii) coarse-grained, 5-15 cm-high symmetric megaripples, $0.5 \mathrm{~m}$ in wavelength (Fig. 11D), with wave ripples in their troughs. Siltstones and shales rest abruptly above the coarse-grained sandstones. BS5 truncates and is overlain by marine deposits. Sedimentary structures in associated coarse-grained sandstones point to processes related to lag deposits in high-energy gravelly shoreface to offshore environments (e.g., Leckie 1988, Hart \& Plint 1989). The coarse-grained sandstone bed represents the only developed transgressive system tract, implying the transgression was non-accretionnary in the Ougarta Range (Helland-Hansen \& Gjellberg 1994).

Above, stacked sandstone-dominated high frequency sedimentary cycles, and deep truncation by the overlying glacially related surface limits sequence stratigraphic interpretations (Fig. 3E). Pre-glacial strata, mostly Sandbian and early Katian (Caradoc and lower Ashgill) in age (Fig. 9) are ascribed to the lower part of a regressive system tract. The regressive system tract extends within the glacially-related strata (Figs 3D, E, 8, 9). The fluviodeltaic sandstones (lower member of the Djebel Serraf Fm.) that fill in palaeovalleys or depressions bounded by a subaerial to subglacial unconformity (Fig. 6) constitute a lowstand wedge at the top of the regressive system tract. The stratigraphic attribution of the glaciomarine and tidal deposits (respectively the middle and upper members of the Djebel Serraf Fm.) will be discussed latter. They are ascribed to the transgressive system tract of a seventh depositional sequence extending into the lower Silurian strata, with a subsequent regressive system tract represented by the Silurian-Early Devonian prograding wedge (Fig. 2).

Regional correlation. - The sixth depositional sequence has a poorly developed transgressive system tract, which may, however, be present to the south, e.g., in the Ahnet, where time-equivalent strata might correspond to sand-flat deposits observed in zones of lesser glacial erosion. To the north in the Anti-Atlas, sedimentation is dominated by severe condensation (phosphatic and/ or ferruginous horizons). Alternatively, the regressive system tract mainly corresponds to the thick Ktaoua Group extending from the lower (but not lowermost) Sandbian to the Katian (lower Caradoc to pre-Hirnantian Ashgill; Destombes et al. 1985, Elaouad-Debbaj 1987, 1988; Bourahrouh et al. 2004). Southward, decreasing thickness of regressive strata in combination with potentially increasing glacial erosion together result in poor preservation of coeval strata, which are, however, locally preserved (Legrand 1985, Kichou-Braîk et al. 2006). On the Arabian Plate, the related maximum flooding surface most probably correlates to the $\mathrm{O} 40$ maximum flooding surface of Sharland et al. (2001). 

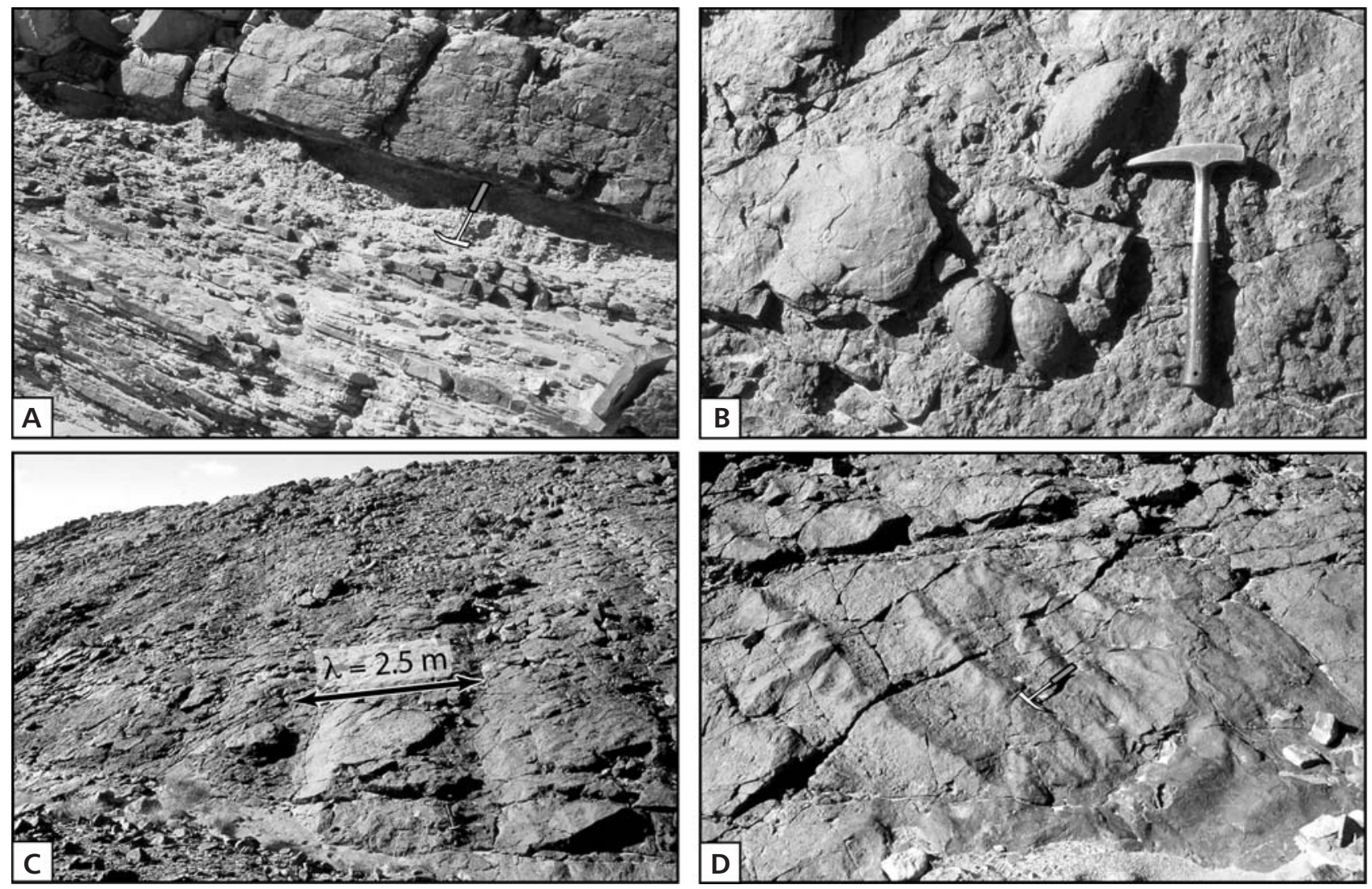

Figure 11. The ferruginous, coarse-grained to conglomeratic sandstone bed underlining the fifth bounding surface (BS5). $\bullet$ A - sharp-based contact on heterolithic, inner-shelf deposits. $\bullet$ B - intraformational rounded pebbles. $\bullet \mathrm{C}$ - large-scale asymmetric current megaripples on bed top. $\bullet$ D - symmetric wave megaripples on bed top.

The erosion surface at the base of glacial deposits is traceable over the whole northern Gondwana. It has been recognised as a major erosional unconformity truncating Ordovician, Cambrian and locally basement rocks where the pre-glacial successions were thin and/or where deep glacial palaeovalleys were cut (Beuf et al. 1971, Ghienne \& Deynoux 1998, Hirst et al. 2002, Eschard et al. 2005, Ghienne et al. in press). Glacial deposits of the Ougarta are correlated unambiguously with the Second Bani Group in the Anti-Atlas (Destombes 1968a, b, Destombes et al. 1985) and with the Felar-Felar Complex or Tamadjert Fm. in the Ahnet or the Tassili (Beuf et al. 1971, Legrand 1985, Eschard et al. 2005; Fig. 10). More precisely, the lower member of the Djebel Serraf Formation is suggested to be time-equivalent with the upper member of the Lower Second Bani Fm. of Destombes et al. (1985) or with the Lower Tichitt Group in Mauritania (Deynoux 1985, Ghienne 2003). These strata record in North Africa the first of two major Hirnantian glacial cycles (Sutcliffe et al. 2000, Štorch 2006, Ghienne et al. in press). The glacial maximum would be represented in the Ougarta Range by the glacial erosion surface at the base of the middle member of the Djebel Serraf Fm (El Kseib Mb., Fig. 6).

\section{Time calibration}

Age attributions based on both biostratigraphic data (Fig. 9) and regional correlation (Fig. 10) indicate that the depositional sequence durations are in the 15-20 Ma range (Fig. 9). The exact number of higher frequency units cannot be determined at outcrop due to poor exposures in fine-grained units and to amalgamation and/or condensation in the transgressive portion of depositional sequences. Three to five short-term sequences per depositional sequence are generally observed and a total number of 5 to 8 can thus be reasonably inferred (Fig. 8). Then, a short-term sequence lasted between 2 and $4 \mathrm{Ma}$. A minimum of four genetic units identified within each of the short-term sequence points to duration in the $0.2-1$ Ma range. As a working hypothesis, it is here proposed that they represent 400 ka-long eccentricity cycles. Those are generally well expressed in the geological record (e.g., Wade \& Pälike 2004) and are considered as the most stable of the Earth's long-term astronomical frequencies (Laskar 1999). As a consequence, the short-term and depositional sequences may be assigned respectively to the third- and second-order sequences of the commonly used hierarchy (e.g., Sharland et al. 2001). Whatever the exact duration of a high 
frequency depositional cycles, they clearly represent orbitally controlled features.

\section{Depositional sequence architecture at platform-scale}

The Cambrian-Ordovician succession thins systematically towards the SE (sediment source area; Fig. 10). Finally, and dealing with non-decompacted thicknesses, 3000 to $5000 \mathrm{~m}$ of fluvial to shallow-marine sediments accumulated rather regularly for around a 100 Ma time interval in the Anti-Atlas, grading to $2000 \mathrm{~m}$ in NW Ougarta, while the coeval succession in SE Ougarta is $1000 \mathrm{~m}$ thick and usually $<500 \mathrm{~m}$ around the Tassili (Fig. 10). This accumulation reflects a globally greater subsidence rate towards the shelf edge.

Although the Ougarta Range only permits us to examine a $200 \mathrm{~km}$-long "window" across each of the six depositional sequences, a stratigraphic architecture can be reconstructed at platform-scale $(\sim 500 \mathrm{~km})$ for an idealised sequence (Fig. 12). With the exception of the glacially-related fluvio-deltaic deposits, the progressive disappearance of the fluvial facies and the development of open marine conditions from the lower to the upper segments of the NW and SE sections is noticeable. This change reflects a long-term and overall southeastward backstepping of the depositional environments from the Cambrian to the Ordovician (Beuf et al. 1971, Fabre \& Kazi-Tani 2005). Therefore, the Ougarta "window" is progressively shifted basinward through time (Fig. 12). Assuming the pre-glacial depositional system did not change significantly, a model for a depositional sequence can be built between two end-members: (i) a proximal one, illustrated by a system tract succession in the lower part of the SE section; and (ii) a distal one, illustrated by a system tract succession in the middle part of the NW section.

A depositional sequence forms an up to $700 \mathrm{~m}$-thick unit bounded by unconformities, which are generally best expressed towards the SE (Fig. 10). Transgressive system tracts mainly form an extensive, 100-300 m-thick, sanddominated sheet-like unit. In the most proximal reaches of the platform, aggrading fluvial to marine sand-flat deposition occurred above the sequence boundary. Continentward backstepping onlaps are responsible for the progressively younger initiation of sediment deposition above the Infra-Tassilian surface. Intervening marine and bioturbated sand-flat deposits represent episodic high-frequency marine flooding (sequence 2). In the coastal portion of the platform, the transgressive system tracts most often comprise an extensively developed sand-dominated succession characterised by aggrading, Skolithos-rich, sand-flat or tidal and shoreface deposits (sequences 3, 5). In some proximal locations, subordinate estuarine facies are deposited and preserved (sequences 2, 3 in the NW section). Basinward (and subsequently), tide and shoreface erosion occurred, favouring the deposition of transgressive lags followed by sedimentary condensation (sequences 5,6). Thick argillaceous sedimentation can, however, occur coevally in the deeper part of the basin below the storm wave base (e.g., Tremadocian shales in the Anti-Atlas), which is likely related to regressive system tracts of short-term T-R sequences or high frequency sedimentary cycles.

In basinal areas, regressive system tracts form relatively thin $(<100 \mathrm{~m})$ to thick $(>300 \mathrm{~m})$ coarsening and thickening upwards heterolithic storm-dominated successions. In the more distal area, continuous sedimentation was generally maintained through a depositional cycle and boundaries are usually not observed in the regressive system tract, which may clearly differentiate highstand from lowstand conditions. In more proximal areas, truncation of regressive shoreface sand occurred, with potential amalgamation of stratigraphic erosion surfaces (subaerial, transgressive ravinements; BS5 in the SE section and BS6). Any fluvial deposit has usually been recognised in the topmost part of regressive system tracts, with the exception of glacially-related strata. Extensive shallow-marine sand flats separating the open shelf from fluvial environments and/or the removing of fluvial sediment during transgressions may explain this feature, independently or in combination. In the more proximal reaches of the platform, regressive system tract deposits basically comprise fining-upwards fluvial successions (depositional sequence 1). Such a trend probably records a lowering of fluvial energy with time in relation to decreasing topographic slope (e.g., Catuneanu 2002). In addition, time-regressive fluvial strata reduced in thickness through time and then disappear as continental environments were progressively shifted southward during the Ordovician into a notably less subsiding area.

\section{Discussion}

\section{Sequence hierarchy}

To develop a system of sequence hierarchy needs a criterion that can be used to differentiate the relative significance of sequences and associated bounding surfaces. Either a system based on boundary frequency, which is equivalent to sequence duration or a system based on the magnitude of base level changes is generally proposed (e.g., Catuneanu 2002 and references therein). For instance, Vail et al. (1991) proposed six orders of boundaries solely defined on boundary frequencies, with eustasy as the main driving factor in boundary generation. Whatever the system used, a primary requirement is that a sequence cannot contain a se- 

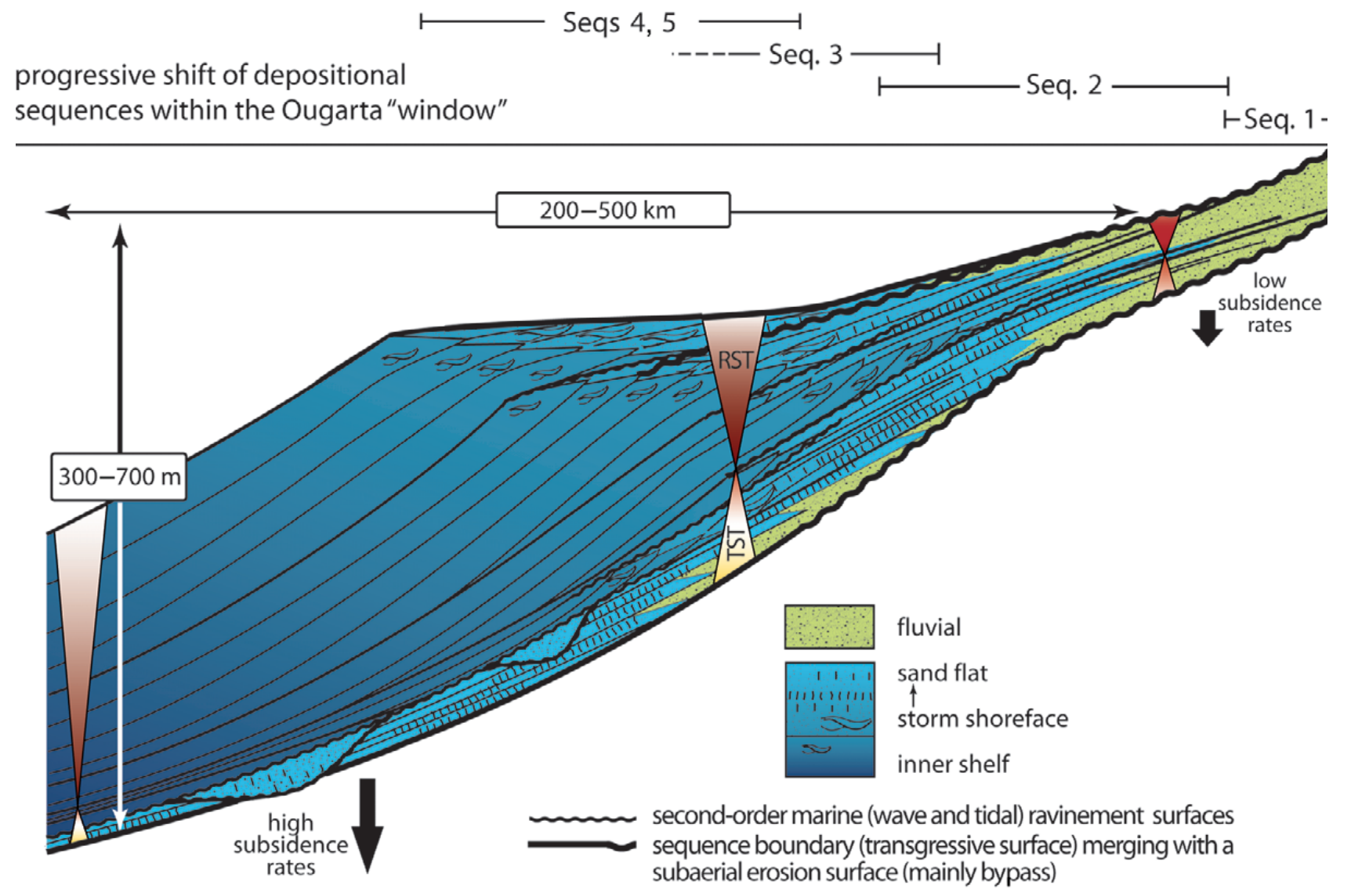

Figure 12. Reconstruction of a Cambrian or Ordovician T-R depositional sequence at the platform scale, assuming no major environmental change in the Ougarta Range through time. Bounding surfaces are transgressive surfaces. They merge to the south with essentially erosional surfaces. Subaerial erosion surfaces or basal surfaces of forced erosion are the most often poorly defined.

quence boundary with the same or lower order than its basal and highest boundary.

Embry (1995) considered that the main pitfall related to this approach using boundary frequency is the potential for subjectivity in picking surfaces of different orders in the sedimentary record. Alternatively, the system based on magnitude of base level changes uses physical attributes, such as the areal extent of the unconformable portion of the sequence boundary or the magnitude of base level rise. Such an approach, which suggests tectonics as the main driving factor for sequence generation can be applied with some success only if basin margins are well defined and preserved (Miall 1997). In addition, stratigraphic architecture is basically controlled by the interplay between sediment supply and rate of base-level change, rather than the magnitude of base level change. It follows that high rates of base level change (e.g., a post-glacial transgression, a rotating block in an extensional setting) may generate prominent boundaries in the stratigraphic record while more continuous base level changes, even if of greater amplitudes, should develop more diffuse sequence boundaries.

Over the North African platform, where tectonic deformation is limited, where the extent of depositional areas can be up to several thousands of kilometres, the use of criteria related to the magnitude of base level changes will inevitably identify glacially related sea-level falls as the major driving factor for the generation of high-order (long term) sequence boundaries despite their short duration relative to long term, tectonically driven processes associated with potentially greater base level changes. This factor is particularly well expressed in the Taoudeni Basin sedimentary record. Here, the Neoproterozoic to Devonian sedimentary cover of the West African Craton has been subdivided by using unconformities intimately associated with the late Neoproterozoic and latest Ordovician glacial successions (Deynoux et al. 1985, 2006). In both cases, severe glacial erosion has emphasised an apparent "angular" unconformity at the basin scale caused by long-term, preglacial, syn-depositional downwarping of the cratonic basement (see below).

We are aware of the problem associated with subjectivity as pointed out by Embry (1995) but we suspect that glacially-related processes (base level fall of great amplitude, oversupplied sediment supply, high rate of base-level rise) may obscure our understanding of the sedimentary record. Hence, to unravel the interference of the Late Ordovician 
glaciation on the Lower Palaeozoic stratigraphic succession, we need a sequence hierarchy independent of base level change, and that is why we have used and advocate a system based on frequency hierarchy to delineate depositional sequences.

\section{Sequence specificities}

Sequence boundaries correspond to erosional truncations that evolve basinward in essentially conformable surfaces with no demonstrable erosion. Whereas erosion confidently reflects local conditions where rate of sea-level fall exceeds subsidence rate, the contribution to erosion of subaerial processes relative to marine ones is unclear. In particular, shallow-marine facies bracket several erosion surfaces and any lowstand valleys have been identified. Moreover, any or minor fluvial deposits have been reported in the basal part of transgressive system tracts (Fig. 8). An additional feature of the depositional sequences is the considerable spatial extent of the sand-bodies, with minor variations in facies occurring over distances $>100 \mathrm{~km}$.

Given that subsidence rates over the platform were of the same order as low-frequency sea-level fluctuation rates, i.e. several tens of metres per million years (e.g., Haq et al. 1987), a transition from relative rise to relative fall occurred on the platform and migrated through time. During periods of long-term sea-level fall, the extent of areas experiencing base-level fall conditions progressively increased (e.g., Catuneanu et al. 1998). These areas include logically proximal southern areas but also some so-called "basement highs" that are laterally adjacent to "depositional troughs". Both types of area correspond to zones of lesser subsidence favouring the erosion of previously deposited shoreface sands during high-frequency transgressions and regressions characterised by higher amplitude and rate of sea-level change. This cannibalization progressively feeds in clastics deeper and more subsiding portions of the platform. When the emersion occurred, erosion virtually ceased. Even in front of the established fluvial system, the subaerial unconformity should not have been incised and is mainly related to sediment bypass (Runkel et al. 1998, Posamentier 2001). Thus it can be speculated that erosion was preferentially associated with shoreface erosion processes rather than with fluvial incision. Long-term normal regression and continuous sedimentation was maintained in the areas with greater subsidence rates, where the effects of high-frequency erosional processes were minimum. This finally resulted in the formation of an extensive but fully diachronous regressive sand-sheet characterising sediment spreading through a long-term cycle in the context of this huge and very flat platform. If the shoreline was located in a sufficiently subsiding area, no longterm forced regression can have developed as aggrading conditions pertain throughout a full cycle of sea-level change.

Runkel et al. (1998) suggested that the formation of sandstone sheets reflected deposition of a continuous sediment supply of sand on a relatively stable, nearly flat basin of slow uniform subsidence during changes in sea level. Independently of possible true basement uplifts, architecture of depositional sequences in the Ougarta moreover suggests a general redistribution of the sediment during a period of low-frequency regressive system tract that might have a widespread geographic extent, displaying similar but diachronous facies successions with regressive and transgressive high-frequency wave reworking of the more shallow reaches of the platform (proximal areas and "basement highs"). Potential, if any, features related to subaerial processes were reworked during the subsequent transgression. The significance of aeolian processes acting on these surfaces is questioned (Fabre 1988). In particular, transgressive sand-rich lithologies may be ascribed to a generalised bypass of the finer-grained material or to the reworking of continental aeolian sand seas, the sand-dominated material of which is easily wave-reworked and spread over the platform in the form of huge sand flats.

\section{Tectonics vs. eustasy}

The Cambrian-Ordovician succession in the Ougarta Range records well organised, possibly periodic, stratigraphic cycles. The basin location, above a paleomargin of the stable West African Craton, which was reactivated during the later stages of the Pan-African orogeny ( $c f$. Geological setting), probably favours a relatively regular subsiding pattern, more active than that characterising adjacent intracratonic domains (e.g., the Taoudeni Basin), but less affected by tectonics than in recently cratonised areas (e.g., the Tuareg shield, Fig. 1) where fault reactivations may have periodically and significantly altered the record of sea-level changes. A long-lasting subsidence pattern and a continuously rising eustatic sea level during the Ordovician as recognised worldwide (Ross \& Ross 1992, Nielsen 2004, Haq \& Al-Qahtani 2005) led to the progressive flooding of the cratonic platform (Fabre 1988, Fabre \& KaziTani 2005). Low frequency depositional sequences, the timing of which is more or less synchronous at least at the scale of the North Gondwana domain (e.g., Sharland et al. 2001, Haq \& Al-Qahtani 2005, Dabard et al. 2007), may record either second order tectono-eustatic cycles or deformation processes at the continent scale. Deformation processes involving the whole of the North African Platform may correspond to the response of the internal continental domain to rifting events occurring at the continental margin. For example, transgressive trends pointing out the lower part of depositional sequences may reflect extensio- 


\section{1-transgression to early regression (low-frequency evolution)}

2- late regression (low-frequency evolution)

\section{3 - transgression to early regression (low-frequency evolution)}

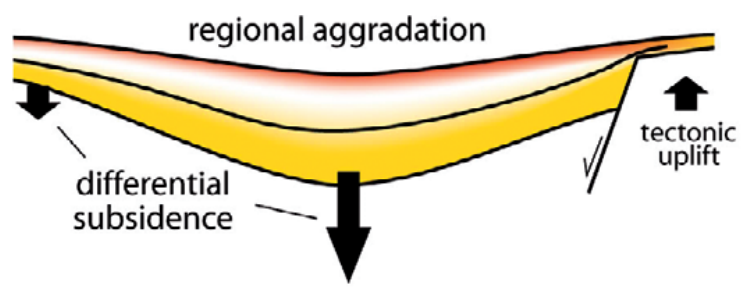

lowstand-induced bypass or erosions tectonically-enhanced lowstand erosion

\section{4-glacio-eustatic sea-level fall (high-frequency event)}

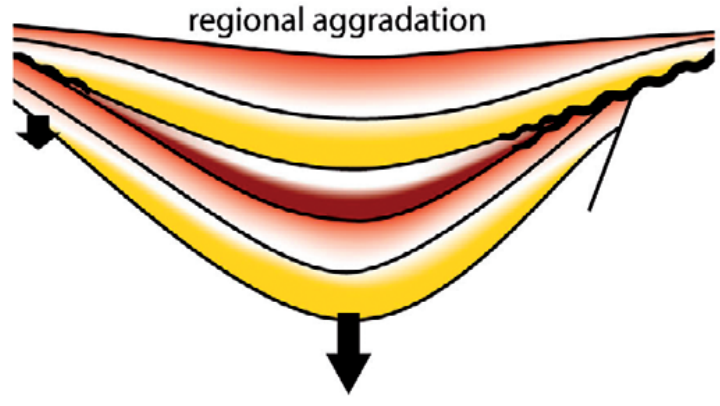

glacial erosion resulting in a disconformity with angular relationships at both basin- and local scales

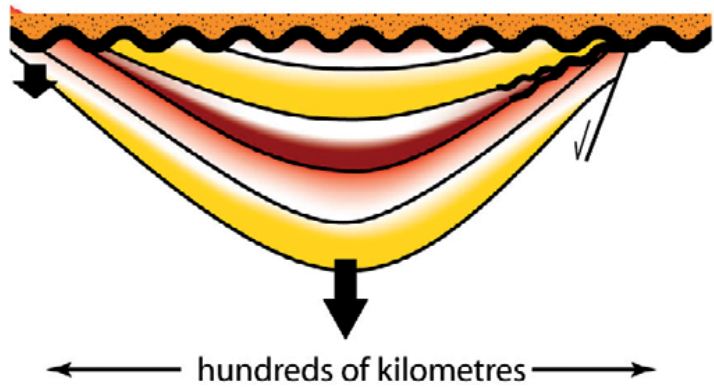

Figure 13. Sketch showing the generation of mappable angular unconformities. They do not represent unconformities related to short-lived tectonic phases but rather reflect large-scale geometries acquired on the long-term and highlighted by high-frequency eustatically-driven erosional truncations (see text for details).

nal tectonic events related to the separation of large continental blocks such as Avalonia (early Darriwilian: Prigmore et al. 1997) or the Hun Superterrane of Stampfli \& Borel (2002) during the Upper Ordovician.

It is outside the scope of this paper to attempt to distinguish the eustatic and tectonic controls on Lower Palaeozoic depositional sequences. Here, because eroded thicknesses at each of the sequence boundaries are most probably limited to ten or tens of metres, we propose that the primary component for the development of depositional sequences in the Cambrian-Ordovician succession of the Ougarta Range is eustatic sea-level change. This is in agreement with the conclusions of Haq \& Al-Qahtani
(2005) who suggest from the Arabian record that during periods of tectonic quiescence, such as the Cambrian-Ordovician period, eustasy have been the significant controlling factor. That is illustrated in particular by essentially penecontemporaneous maximum flooding conditions from the Ougarta to the Arabian Plate (Sharland et al. 2001; Fig. 9). During periods of sea-level rise, accommodation related to sea-level change was cumulative with subsidence and thus attenuated the stratigraphic signature of potential tectonic uplift. Alternatively, during periods of sea-level fall, the long-term rate of sea-level fall durably exceeded rate of subsidence resulting in erosional unconformities and then amplifying the stratigraphic signature of 
potential tectonic uplift. Mappable angular unconformities can appear in areas where differential subsidence rates existed prior to erosion (Fig. 13). They do not represent unconformities related to short-lived tectonic phases but large-scale geometries acquired on the long-term and highlighted by eustatically-driven erosional truncation corresponding to composite, amalgamated, subaerial or transgressive erosion surfaces during repeated high-frequency to short-term sea-level fluctuations. The more the amplitude of eustatic sea-level fall, the falsely greater the apparent tectonic event will appear (Fig. 13). Nevertheless, outside the Ougarta, localised but significant deformation events did occur close to Pan-African lineaments in response to stress at the continental margin. Such uplifts are well known in Algeria, where there might have resulted from the superimposition of Dapingian or early Darriwilian (i.e. Upper Arenig) strata on Tremadocian via an erosion surface (e.g., Oulebsir \& Paris 1995). In the Ahnet area, Beuf et al. (1971) have demonstrated that these uplifts were located above lithospheric structures prone to be reactivated.

\section{A transgressive megasequence}

From the Cambrian to Late Ordovician, successive depositional sequences show: (1) progressive disappearance of fluvial facies; (2) thinning of transgressive system tracts; and (3) development of repetitive open marine conditions from the lower part of sections onwards and from the NW to the SE Ougarta. These relationships that designate retrogradational architecture on the long term indicate that the Cambrian-Ordovician succession corresponds to a first-order transgressive system resulting in a step-by-step flooding of the North African Platform. This view do not support the Sharland et al. (2001) stratigraphic scheme, within which the Cambrian-Ordovician succession represents as a whole a single tectono-stratigraphic sequence.

The preservation of this thick transgressive system, though deposited in the context of a continuously rising eustatic sea level, implies in addition the progressive southeastward migration of the depositional edge from the Cambrian to the Ordovician. While a continuously subsiding platform occurred toward the north (e.g., Anti-Atlas), subsidence was initiated in progressively more and more southern areas with differential subsidence patterns, contrasting depositional troughs and basement highs. Timing of this overall onlap relationship of Cambrian-Ordovician strata on the basement is supported by biostratigraphy and provenance studies. First, open marine conditions reached the most internal areas of the platform only during the Upper Ordovician. Near the Algeria-Mali boundary, i.e. $600 \mathrm{~km}$ south of the Ahnet area (right section in Fig. 10), Gatinski et al. (1966) documented the occurrence of biostratigraphically dated Upper Ordovician deposits bearing graptolites, trilobites and brachiopods above a thin $(<20 \mathrm{~m})$ cross-stratified barren sandstone unit resting on the Neoproterozoic basement. Second, studies based on detrital zircons show that those of Pan-African age are predominant in Cambrian strata (matching the more arkosic nature of the sandstones) whereas they progressively disappear in parallel with the significant increase in proportion of zircons with older ages (> 1Ga). Therefore, the blanketing of the Pan-African sediment source is inferred and a many hundreds of kilometres southward migration of the source area is suggested (Avigad et al. 2003, Kolodner et al. 2006).

\section{The Ordovician maximum flooding}

If the Cambrian-Ordovician succession represents a transgressive system for the North Gondwana Lower Palaeozoic strata, what is the corresponding maximum flooding surface? (i.e. the stratigraphic surface marking in the long term the end of the shoreline transgression and separating retrograding to prograding strata).

It is generally recognised that higher eustatic sea levels were achieved during the Late, but not the latest, Ordovician (e.g., Ross \& Ross 1992, Nielsen 2004, Haq \& Al-Qahtani 2005). The first-order maximum flooding surface (MFS) representing the culmination of the Cambrian-Ordovician shoreline transgression should have been Late Ordovician or older. Without the incidence of the Hirnantian glaciation, the Ordovician MFS should have been coincident with one of the second-order maximum flooding surfaces between the Middle and the Upper Ordovician, depending on relationships between rates of long-term sea-level rise and subsidence. Spatial variations in subsidence may induce stratigraphic sequence distortion with the onset of progradation delayed in the more subsiding area (Robin et al. 2005). In areas experiencing limited subsidence ( 5-10 m/Ma, e.g., the Taoudeni Basin in Mauritania or the Murzuq Basin in Libya), the Ordovician MFS might have occurred as early as the lower Middle Ordovician (early Darriwilian, i.e. formosa event sensu Paris et al. 2007 of early Llanvirn age), when rates of sea-level rise were greater, resulting in a general backstepping of the shorelines throughout the platform. In more subsiding areas such as the Ougarta $(\sim 10-20 \mathrm{~m} / \mathrm{Ma})$, or the Anti-Atlas (> $30 \mathrm{~m} / \mathrm{Ma})$, the Ordovician MFS may have been notably younger (Late Ordovician) and have been established when rate of sea-level rise had already noticeably declined. However, it must be born in mind that some restrictions to this oversimplified view such as long-term basinward migration of the shoreline from an internal and slowly subsiding area, which experienced sediment bypass or reworking, toward distal faster subsiding areas, most probably forced 


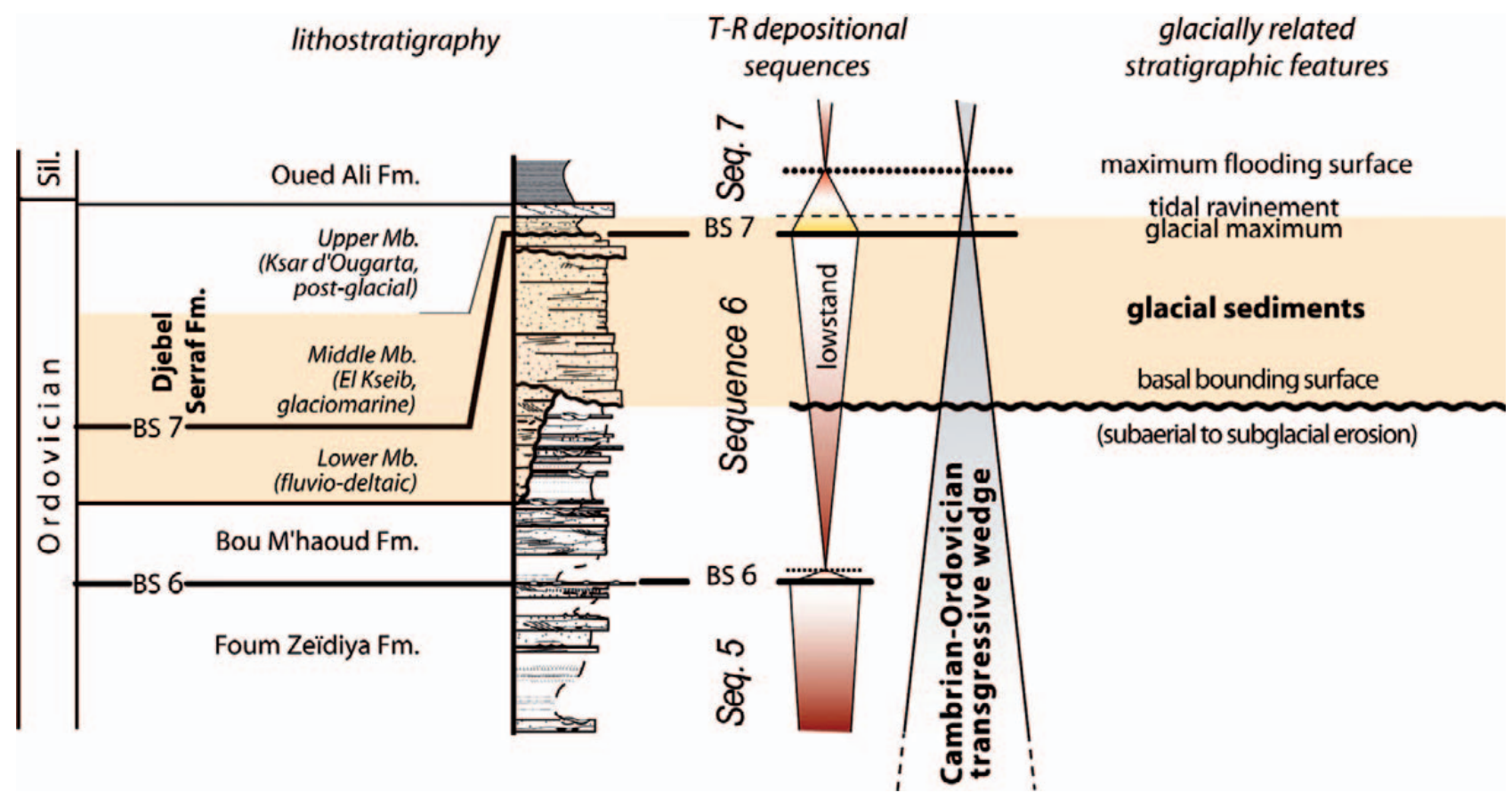

Figure 14. The Hirnantian glacial event in the context of the Cambrian-Ordovician transgression. Just before the end of this first-order, continent-wide transgression initiating in the Cambrian, the high-frequency Late Ordovician glaciation and especially the Hirnantian event only temporarily perturbed its overall backstepping trend.

the onset of progradation in the latter. Nevertheless, at the scale of a north Gondwana basinal area such as the Ougarta, these relationships may be used to explain some timing discrepancies between sedimentary basins.

The occurrence of the Hirnantian glaciation that mimics a major regressive trend, responsible for high-frequency sea-level fluctuations, with the development of extensive sand-dominated fluvio-deltaic strata has to be discussed in the context of the final stages of this Cambrian-Ordovician transgression (Fig. 14).

\section{Significance of the Late Ordovician glacial event}

The basal bounding surface of the glacially related strata is considered as an ideal allostratigraphic discontinuity (Fig. 14). It is well defined and synchronous (base of Hirnantian) at the geological time scale everywhere in North Gondwana (Ghienne et al. in press and references therein). Based on its prominent erosional character, this bounding surface is generally considered to be a major unconformity that includes a tectono-stratigraphic component and separating two major, long-term depositional sequences (Sharland et al. 2001, Carr 2002, Eschard et al. 2005). The overlying glacially related strata are sometimes regarded as an individual major depositional sequence (Fekirine \& Abdallah 1998, Eschard et al. 2005). However, using a system of sequence hierarchy based on boundary frequency, we consider that this surface has no greater significance than that of other sequence boundaries documented in the underlying Cambrian-Ordovician succession. The surface can be ascribed to a subaerial (to subglacial) erosion underlining a lowstand wedge of an Exxon-type depositional sequence. Based on the restricted (0.5-2 Ma) time interval that corresponds to the Hirnantian glaciation (Brenchley et al. 1994, 2003; Paris et al. 1995; Sutcliffe et al. 2000; Ghienne et al. in press), we consider that glacially related strata cannot be assimilated alone into a depositional sequence but rather represent a short-term sequence or possibly at most a couple of genetic units.

Using transgressive surfaces for the delineation of T-R depositional sequences, a seventh bounding surface is naturally identified within the glacially related strata (Fig. 14). It corresponds to the glacial surface constituting the lower bounding surface of the glaciomarine deposits (middle member of the Djebel Serraf Fm.) above which a noticeable transgressive trend is expressed from glacial environments to non-glacial offshore shelf environments (Fig. 6). This surface most probably reflects the Hirnantian ice-maximum, which usually occurs in the upper half of the glacial wedge (Ghienne et al. in press), a correlation that makes sense with overlying strata deposited during an overall sea-level rise. Whereas the geometry of this surface essentially results from glacial erosion, its stratigraphic significance corresponds to a transgressive surface. It over- 
lies fluvio-deltaic deposits at the top of the regressive system tract of the sixth depositional sequence and then forms the basal bounding surface of a seventh T-R depositional sequence.

Similar relationships, attributing the younger Hirnantian glacial strata to a transgressive system tract extending in the Silurian have also been described from the glacial record in Mauritania (Ghienne 2003). A maximum flooding surface can be pointed out for this seventh sequence in the lowermost Silurian (Lüning et al. 2000, surface S10 of Sharland et al. 2001), a time interval from which the shoreline renewed to migrate northward and even if deepening conditions were maintained northward by a low rate of offshore transport and locally by subsidence patterns. The seventh depositional sequence further includes the overlying Silurian strata, which correspond throughout North Gondwana to a well known prograding wedge (Bellini \& Massa 1980, Lüning et al. 2000, Eschard et al. 2005) constituting its regressive system tract.

The Hirnantian glaciation has been responsible for: (i) considerable basal erosion, affecting the whole of the platform, with erosion depths in places greater than $300 \mathrm{~m}$ (Ghienne et al. in press, and references therein); (ii) the onset of continental conditions, either fluvial or subglacial, which arose quite instantaneously throughout the platform with sedimentation directly influenced by glaciers recognised from the Anti-Atlas to Southern Algeria; and (iii) very high rates of sea-level change, both within and at the end of the glaciation (post-glacial transgression). The glacial erosion, which was deeper and faster than all other preglacial erosion processes, led to a stratigraphic discontinuity along which latest Ordovician rests at first-order on progressively older strata toward the south (Fig. 10); Upper Ordovician to the north of the platform (e.g., Destombes 1968a, b, Bourahrouh et al. 2004), then Middle and Lower Ordovician in intermediate areas (e.g., Oulebsir \& Paris 1995) and then Cambrian or basement rocks southwards (Beuf et al. 1971). The discontinuity, angular at the basin scale, truncates noticeably older basin-wide or localised syn-depositional deformation structures, falsely suggesting a major tectonic deformation event, sometimes related to the so-called Taconic unconformity, which would have occurred just prior to glaciation onset (e.g., Crossley \& McDougall 1998, Eschard et al. 2005). For example, in a number of areas located between the Ahnet and the Ougarta (figured by an oversimplified horst structure in Fig. 10), glacial strata rest on Lower Ordovician or Cambrian strata (Legrand 1985). This unconformable contact, highlighted by glacial erosion, is regarded as mainly reflecting deformation structures that affected deposition during the late Early Ordovician (Beuf et al. 1971; Fig. 13). In our scheme, there is no reason to attribute any tectono-stratigraphic value to the basal bounding surface of the glacially related strata.
The subsequent post-glacial transgression, which was very fast relative to the Cambrian-Ordovician tempo, resulted in a non-accretionary transgression (e.g., HellandHansen \& Gjellberg 1994) with a drastic southward backstepping of the shoreline during which post-glacial sedimentation dominated over the main part of the platform with in-situ wave or tidal reworking (Fig. 7; e.g., Ghienne 2003, Moreau 2005). As a consequence, the combination of glacial erosion and post-glacial high rate of sea-level rise forced shorelines to shift drastically to the south. Early Silurian shorelines reach the south of the Koufra Basin (Libya-Chad boundary; Lüning et al. 2000), and were located south of the Djado area in Niger (Legrand 2003, Denis et al. 2007) or to the SE of the Hodh area in Mauritania (Paris et al. 1998, Ghienne 2003). From these southern locations, Silurian shorelines have then migrated throughout the platform to the NW (Bellini \& Massa 1980, Lüning et al. 2000).

\section{Conclusions}

The Silurian flooding on the North Gondwana platform may be regarded as the end product of the Cambrian-Ordovician transgression, with specific features enhanced by the high-frequency Hirnantian glacial event. High sea levels of the Late Ordovician period were abruptly restored on the platform with latest Ordovician shorelines shifted southward relative to all other Late Ordovician shorelines. The global and virtually instantaneous nature of the Hirnantian glacial event has "synchronised" the stratigraphic architecture of the succession throughout the platform. At the end of the post-glacial transgression, a second-order maximum flooding occurred everywhere, whatever the local rate of subsidence, near the Ordovician-Silurian boundary or more probably within the earliest Silurian. This event, which also marks the first-order inversion trend between generally retrograding strata of the Cambrian-Ordovician succession and a prograding Siluro-Devonian wedge, corresponds to the maximum flooding of the Lower Palaeozoic transgressive-regressive megasequence in North Africa. Just before the end of this first-order, continent-wide transgression initiating in the Cambrian, the Late Ordovician glaciation, and especially the Hirnantian event, only temporarily perturbed its overall backstepping trend.

\section{Acknowledgments}

The authors are indebted to the SONATRACH (Algerian National Oil Company) for logistic and scientific support during fieldwork in the Algerian Sahara. One of us (B.V.) benefited from a post-doctoral grant from TOTAL S.A. The authors are grateful to J. Frýda, M. Mergl and P. Štorch (Czech Republic) as well as 
E. Villas (Spain), M. Vidal and J. Vannier (France) for preliminary faunal identifications. They also thank O. Fatka, P. Kraft and O.E. Sutcliffe, for reviewing and greatly improving the manuscript. This is a contribution of EOST (Ecole et Observatoire des Sciences de la Terre) number 2007.501 - UMR 7517 to the ECLIPSE II (CNRS, France) and to IGCP 503 projects.

\section{References}

Albani, R., Massa, D. \& Tongiorgi, M. 1991. Palynostratigraphy (Acritarchs) of some Cambrian beds from the Rhadames (Ghadamis) Basin (Western Libya-Southern Tunisia). Bolletino della Società Paleontologica Italiana 30, 255-280.

Álvaro, J.J., VAN Vliet-LANOË, B., VENNIN, E. \& BlANC-VALLERON, M.M. 2003a. "Lower" Cambrian paleosols from the Cantabrian Mountains (northern Spain): a comparison with Neogene-Quaternary analogues. Sedimentary Geology 163, 67-84.

Álvaro, J.J., GONZÁlEZ-GómEZ, C. \& VizCAÏNO, D. 2003b. Paleogeographic patterns of the Cambrian-Ordovician transition in the southern Montagne Noire (France): preliminary results. Bulletin de la Société géologique de France 174/3, 23-31.

ARBEY, F. 1962. Données nouvelles sur la sédimentation au Cambro-Ordovicien dans les Monts d'Ougarta (Saoura). Comptes rendus de l'Académie des sciences, Paris 254, 3726-3728.

ARBEY, F. 1968. Structures et dépôts glaciaires dans l'Ordovicien terminal des chaînes d'Ougarta (Sahara algérien). Comptes rendus de l'Académie des sciences, Paris 268, 76-78.

ARBEY, F. 1971. Glacio-tectonique et phénomènes périglaciaires dans les dépôts siluro-ordoviciens des monts d'Ougarta (Sahara algérien). Comptes rendus de l'Académie des sciences, Paris 273, 854-857.

ARBEY, F. 1988. Diagénèses précoces et tardives: silicifications et roches silico-détritiques. $521 \mathrm{pp}$. Thèse de doctorat d'état, Université de Paris-Sud, France.

ARBEY, F. \& CABY, R. 1966. Présence de dreikanters à la base du Cambrien de la Sebkha el Melah; remarques sur la discordance du Paléozoïque et sur l'âge du soubassement dans la région des Monts d'Ougarta (Sahara algérien). Comptes rendus sommaires de la Société géologique de France, 63-64.

Avigad, D., Kolodner, K., MCWilliams, M., Persing, H. \& WEISSBROD, T. 2003. Origin of northern Gondwana Cambrian sandstone revealed by detrital zircon SHRIMP dating. Geology 31, 227-230.

AVIGAd, D., SANDler, A., Kolodner, K., STERn, R.J., MCWILLIAMS, M., MILLER, N. \& BEYTH, M. 2005. Mass-production of Cambro-Ordovician quartz-rich sandstone as a consequence of chemical weathering of Pan-African terranes: environmental implications. Earth and Planetary Science Letters 240, 818-826.

BELLINI, E. \& MASSA, D. 1980. A stratigraphic contribution to the Paleozoic of the Southern Basins of Libya, 1-56. In SALEM, M.J. \& Buswell, M.T. (eds) Geology of Libya I. Academic Press, London.

BENOÎT, A. \& TAUGOURDEAU, P. 1961. Sur quelques chitinozoaires de l'Ordovicien du Sahara. Revue de l'Institut Français du Pétrole 16, 1403-1421.

Beuf, S., BiJu-Duval, B., De Charpal, O., Rognon, P., GARIEl, O. \& BENNACEF, A. 1971. Les grès du Paleozoïque inférieur au Sahara. 464 pp. Science et Technique du Pétrole 18, Paris.
Boote, D.R.D., Clark-Lowes, D.D. \& Traut, M.W. 1998. Paleozoic petroleum systems of North Africa, 7-68. In MACGREGOR, D.S., MOODY, R.T.J. \& CLARK-LOWES, D.D. (eds) Petroleum Geology of North Africa, Geological Society London Special Publication 132.

Bourahrouh, A., Paris, F. \& Elaouad-DebBaj, Z. 2004. Biostratigraphy, biodiversity and palaeoenvironments of the chitinozoans and associated palynomorphs from the Upper Ordovician of the Central Anti-Atlas, Morocco. Palaeogeography, Palaeoclimatology, Palaeoecology 130, 17-40.

BRENCHLEY, P.J., RoMANO, M. \& GUTIÉRREZ-MARCO, J.C. 1986. Proximal and distal hummocky cross-stratification facies on a wide Ordovician shelf in Iberia, 241-255. In KNIGHT, R.J. \& MCLEAN, J.R. (eds) Shelf sands and sandstones. Memoir Canadian Society Petroleum Geologists II.

Brenchley, P.J., MARShall, J.D., CARdEN, G.A.F., Robertson, D.B.R., LONG, D.G.F., MEIDLA, T., HinTS, L. \& ANDERSON, T.F. 1994. Bathymetric and isotopic evidence for a short-lived Late Ordovician glaciation in a greenhouse period. Geology 22, 295-298.

Brenchley, P.J., Carden, G.A., Hints, L., Kaljo, D., MaRShall, J.D., Martma, T., Meidla, T. \& NolvaK, J. 2003. High-resolution stable isotope stratigraphy of Upper Ordovician sequences: Constraints on the timing of bioevents and environmental changes associated with mass extinction and glaciation. Bulletin of the Geological Society of America 115, 89-104.

Burke, K. \& KraUS, J.U. 2000. Deposition of immense CambroOrdovician sandstone bodies, now exposed mainly in north Africa and Arabia, during the aftermath of the final assembly of Gondwana. Geological Society of America Abstracts with Program 32(7), 249.

Burkhard, M., Caritg, S., Helg, U., Robert-Charrue, C. \& Soulaimani, A. 2006. Tectonics of the Anti-Atlas of Morocco. Comptes Rendus Geosciences 338, 11-24.

CABY, R. 1996. Rapport de mission de terrain dans le Grand Sud-Ouest Algérien. Mémoires du Service géologique d'Algérie $8,49-51$.

CARR, I.D. 2002. Second-order sequence stratigraphy of the Palaeozoic of North Africa. Marine Petroleum Geology 25, 259-280.

CATUNEANU, O. 2002. Sequence stratigraphy of clastic systems: concepts, merits, and pitfalls. Journal of African Earth Science $35,1-43$.

Catuneanu, O., WiLlis, A.J. \& Miall, A.D. 1998. Temporal significance of sequence boundaries. Sedimentary Geology 121, 157-178.

CLIFTON, H.E. 1976. Wave-formed sedimentary structures - a conceptual model, 126-148. In DAVIS, R.A., JR. \& ETHINGTON, R.L. (eds) Beach and Nearshore Sedimentation. Society of Economic Paleontogists and Mineralogists, Special Publication 24.

Crossley, R. \& MCDougall, N. 1998. Lower Palaeozoic reservoirs of North Africa, 157-166. In MACGREGOR, D.S., MOODY, R.T.J. \& CLARK-LOWES, D.D. (eds) Petroleum Geology of North Africa. Geological Society London Special Publication 132.

DABARD, M.P., LOI, A. \& PARIS, F. 2007. Relationship between phosphogenesis and sequence architecture: sequence stratigraphy and biostratigraphy in the Middle Ordovician of the Armorican Massif (W France). Palaeogeography, Palaeoclimatology, Palaeoecology 248, 339-356. 
DEAN, W.T. 2005. Trilobites from the Cal Tepe Formation (Cambrian), near Seydisehir, Central Taurides, south-western Turkey. Turkish Journal of Earth Sciences 13, 1-71.

DEAN, W.T. \& MONOD, O. 1990. Revised stratigraphy and relationships of Lower Palaeozoic rocks, eastern Taurus Mountains, south central Turkey. Geological Magazine 127, 333-347.

Denis, M., BuOncRistiani, J.-F., Konaté, M., GHIEnNE, J.-F. \& GUIRAUD, M. 2007. Hirnantian glacial and deglacial record in SW Djado Basin (NE Niger). Geodinamica Acta 20(3), 177-194.

DESTOMBES, J. 1968a. Sur la présence d'une discordance générale de ravinement d'âge Ashgill supérieur dans l'Ordovicien terminal de l'Anti-Atlas (Maroc). Comptes rendus de l'Académie des sciences, Paris 267 D, 565-567.

DESTOMBES, J. 1968b. Sur la nature glaciaire des sédiments du groupe du $2^{\mathrm{e}}$ Bani, Ashgill supérieur de l'Anti-Atlas, Maroc. Comptes rendus de l'Académie des sciences, Paris 267 D, 684-686.

Destombes, J. \& Feist, R. 1987. Découverte du Cambrien supérieur en Afrique (Anti-Atlas, Maroc). Comptes rendus de l'Académie des sciences, Paris 304, 719-724.

Destombes, J., Hollart, H. \& WiLlefert, S. 1985. Lower Paleozoic rocks of Morocco, 291-325. In HollaND, C.H. (ed.) Lower Paleozoic Rocks of northwest and west Central Africa. John Wiley, New York.

DEYNOUX, M. 1985. Terrestrial or waterlain glacial diamictites? Three case studies from the Late Precambrian and Late Ordovician glacial drifts in West Africa. Palaeogeography, Palaeoclimatology, Palaeoecology 51, 97-141.

DeynouX, M., Sougy, J. \& TROMPETTE, R. 1985. Lower Paleozoic rocks of West Africa and the western part of Central Africa, 337-495. In Holland, C.H. (ed.) Lower Paleozoic Rocks of northwest and west Central Africa. John Wiley, New-York.

DeYnouX, M. \& GHIENNE, J.-F. 2004. Late Ordovician glacial pavements revisited - a reappraisal of the origin of striated surfaces. Terra Nova 16, 95-101.

Deynoux, M., AfFaton, P., Trompette, R. \& Villeneuve, M. 2006. Pan-African tectonic evolution and glacial events registered in Neoproterozoic to Cambrian cratonic and foreland basins of West Africa. Journal of African Earth Science 46, 397-426.

DonzEAU, M. 1971. Etude structurale dans le Paléozö̈que des Monts d'Ougarta. 100 pp. Thèse de doctorat, Faculté des Sciences, Orsay, France.

DONZEAU, M. 1974. L'Arc Anti-Atlas - Ougarta (Sahara nord-occidental, Algérie-Maroc). Comptes rendus de l'Académie des sciences, Paris 278, 417-420.

DONZEAU, M. 1983. Tectonique des monts d'Ougarta, 118-120. In FABRE, J. (ed.) Afrique de l'Ouest, Introduction Géologique et termes stratigraphiques. Lexique stratigraphique international, Nouvelle série 1. Pergamon Press, Oxford.

DuMAS, S. \& ARNOTT, R.W.C. 2006. Origin of hummocky and swaley cross-stratification - The controlling influence of unidirectional current strength and aggradation rate. Geology 34, 1073-1076.

Elaouad-DebBaj, Z. 1987. Acritarches et Chitinozoaires de l'Ordovicien du Maroc. Systématique, Biostratigraphie, corrélations. 310 pp. Thèse de doctorat, Université de Rennes I (unpublished).

ElAOUAD-DEBBAJ, Z. 1988. Acritarches et chitinozoaires du Tremadoc de l'Anti Atlas central (Maroc). Revue de micropaléontologie 31, 85-128.
EMBRY, A.F. 1995. Sequence boundaries and sequences hierarchies: problems and proposals, 1-11. In STEEL, R.J., FELT, V.L., JOHANNESEN, E.P. \& MATHIEU, C. (eds) Sequence stratigraphy on the Northwest European Margin. Norwegian Petroleum Society, Special Publication 5.

ENNIH, N. \& LIÉGEOIS, J.-P. 2001. The Moroccan Anti-Atlas: the West African passive margin with limited Pan-African activity. Precambrian Research 112, 289-302.

Eschard, R., Abdallah, H., Braik, F. \& Desaubliaux, G. 2005. The Lower Paleozoic succession in the Tasilli outcrops, Algeria: sedimentology and sequence stratigraphy. First Break $23,27-36$.

FABRE, J. 1988. Les séries paléozoïques d'Afrique: une approche. Journal of African Earth Science 7, 1-40.

FABRE, J. 2005. Le Précambrien terminal - Cambrien: glaciation et enterrement d'une chaîne panafricaine, 117-144. In FABRE, J. (ed.) Géologie du Sahara occidental et central. Tervuren African Geoscience Collection 108. Musée Royal de l'Afrique Centrale, Tervuren.

FABRE, J. \& KAZI-TANI, N. 2005. Ordovicien, Silurien, Devonien, Permo-Carbonifère, 147-360. In FABRE, J. (ed.) Géologie du Sahara occidental et central. Tervuren African Geoscience Collection 108. Musée Royal de l'Afrique Centrale, Tervuren.

FABRE, J., AIT-KACI, A., Bouima, T. \& Moussine-Pouchkine, A. 1988. Le cycle molassique dans le rameau trans-saharien de la chaîne panafricaine. Journal of African Earth Science 7, 41-55.

FAIK, F., BELFOUL, M.A., BOUABDELLI, M. \& HASSENFORDER, B. 2001. Les structures de la couverture Néoprotérozoïque terminal et Paléozoïque de la region de Tata, Anti-Atlas centre occidental, Maroc: deformation polyphasée, ou interactions socle/couverture pendant l'orogenèse hercynienne. Journal of African Earth Science 32, 765-776.

FEKIRINE, B. \& ABDALLAH, H. 1998. Palaeozoic lithofacies correlatives and sequence Stratigraphy of the Sahara Platform, Algeria, 97-108. In MACGREGOR, D.S., MOODY, R.T.J. \& CLARK-LOWES, D.D. (eds) Petroleum Geology of North Africa. Geological Society London Special Publication 132.

GATINSKI, G., KLOTCHKI, V.P., ROZMAN, K.S. \& TROFIMOV, D.M. 1966. Nouvelles données sur la stratigraphie des dépôts paléozoïques du Sahara méridional. Doklady Akademii nauk SSSR 170, 1154-1157.

GHIENNE, J.-F. 2003. Late Ordovician sedimentary environments, glacial cycles, and post-glacial transgression in the Taoudeni Basin, West Africa. Palaeogeography, Palaeoclimatology, Palaeoecology 189, 117-145.

GHIENNE, J.-F. \& DEYNouX, M. 1998. Large-scale channel fill structures in Late Ordovician glacial deposits in Mauritania, western Sahara. Sedimentary Geology 119, 141-159.

Ghienne, J.-F., Le Heron, D., Moreau, J., Denis, M. \& DEYNOUX, M. In press. The Late Ordovician glacial sedimentary system of the North Gondwana platform. In HAMBREY, M., Christoffersen, P., Glasser, N., JANSSEN, P., HubBARD, B. \& SIEGERT, M. (eds) Glacial sedimentary processes and products. International Association of Sedimentologists, Special Publication 39. Blackwells, Oxford.

GomeZ Silva, M., PACAUd, M. \& WIEL, F. 1963. Contribution à l'étude du Cambro-Ordovician des chaînes d'Ougarta (Sahara algérien). Bulletin de la Société géologique de France 7, 134-141. 
GuTIÉRREZ-MARCO, J.C., DESTOMBES, J., RÁBANO, I., ACEÑOLAZA, G.F., SARMIENTO, G.N. \& SAN José, M.A. 2003. El Ordovícico Medio del Anti-Atlas marroquí: paleobiodiversidad, actualización bioestratigráfica y correlación. Geobios 36, 151-177.

HAMPSON, G.J. 2000. Discontinuity surfaces, clinoforms, and facies architecture in a wave-dominated, shoreface-shelf parasequence. Journal of Sedimentary Research 70, 325-340.

HAQ, B.U. \& AL-QAHTANI, A.M. 2005. Phanerozoic cycles of sea-level change on the Arabian Platform. GeoArabia 10, $127-160$.

HAQ, B.U., HARDENBOL, J. \& VAIL, P.R. 1987. Chronology of fluctuating seal levels since the Triassic. Science 235, 1156-1166.

HARMS, J.C., SOUTHARD, J.B. \& WALKER, R.G. 1982. Structures and sequences in clastics rocks. Society for Sedimentary Geology (SEPM) Short Course 9, 1-253.

HART, B.S. \& PLINT, A.G. 1989. Gravelly shoreface deposits; a comparaison of modern and ancient facies sequences. Sedimentology 36, 551-557.

Helland-Hansen, W. \& GJELlBeRG, J.G. 1994. Conceptual basis and variability in sequence stratigraphy: a different perspective. Sedimentary Geology 92, 31-52.

HeRvoueT, Y. \& DUEE, G. 1996. Analyse morphostructurale par imagerie satellitaire et coupes structurales modélisées des monts d'Ougarta (Sahara occidental, Algérie): une chaîne hercynienne chevauchante à plis passifs. Mémoires du Service géologique de l'Algérie 8, 127-173.

Hirst, J.P.P., BENBAKIR, A., PAYNe, D.F. \& WeStlake, I.R. 2002. Tunnel valleys and density flow processes in the upper Ordovician glacial succession, Illizi Basin, Algeria: influence on reservoir quality. Marine Petroleum Geology 25, 297-324.

Kichou-BraîK, F., SAMAR, L., FeKIRINE, B. \& Legrand, P. 2006. Découverte de graptolites d'âge Caradocien dans quelques sondages du Tinrhert (Sahara algérien). Comptes Rendus Palevol 5(5), 675-683.

KILIAN, C. 1922. Aperçu général de la structure des Tassilis, des Ajjers. Comptes rendus de l'Académie des sciences, Paris 175, 825-827.

Kolodner, K., Avigad, D., MCWilliams, M., Wooden, J.L., WeIsSBROD, T. \& FEINSTEIN, S. 2006. Provenance of north Gondwana Cambrian-Ordovician sandstone: U-Pb. SHRIMP dating of detrital zircons from Israel and Jordan. Geological Magazine 143, 367-391.

LANDING, E., GeYer, G. \& HeldMaIER, W. 2006. Distinguishing eustatic and epeirogenic controls on Lower-"Middle" Cambrian boundary successions in West Gondwana (Morocco and Iberia). Sedimentology 54, 899-918.

LASKAR, J. 1999. The limits of Earth orbital calculations for geological time-scale use. Philosophical Transactions of the Royal Society of London A 357, 1735-1759.

LECKIE, D.A. 1988. Wave-formed, coarse-grained ripples and their relationship to hummocky cross-stratification. Journal of Sedimentary Petrology 58, 607-622.

LEDRU, P., AUtRAN, A. \& SANTALliER, D. 1994. Lithostratigraphy of Variscan terranes in the French Massif Central: a basis for paleogeographical reconstruction, 226-288. In KEPPIE, J.D. (ed.) Pre-Mesozoic geology in France and related areas. Springer, Berlin.

LE HeRon, D.P., SUTCLifFE, O.E., WhitTington, R.J. \& CRAig, J. 2005. The origins of glacially related soft-sediment deformation structures in Upper Ordovician glaciogenic rocks: implication for ice sheet dynamics. Palaeogeography, Palaeoclimatology, Palaeoecology 218, 75-103.

LEGRAND, P. 1964. Un graptolite intéressant de l'Arénigien supérieur du Sahara algérien: Didymograptus v-fraactus wieli nov. subsp. Comptes rendus sommaires de la Société géologique de France 9, 360-363.

LEGRAND, P. 1966. Précisions biostratigraphiques sur l'Ordovicien inférieur et le Silurien des chaînes de l'Ougarta (Sahara algérien). Comptes rendus sommaires de la Société géologique de France 97, 243-245.

LEGRAND, P. 1974. Essai sur la paléogéographie de l'Ordovicien du Sahara algérien. Compagnie Française des Pétroles, Notes et Mémoires 11, 121-138.

LEGRAND, P. 1985. Lower Palaeozoic rocks of Algeria, 5-89. In Holland, C.H. (ed.) Lower Paleozoic Rocks of northwest and west Central Africa. John Wiley, New York.

LEGRAND, P. 1988. The Ordovician-Silurian boundary in the Algerian Sahara, 139-143. In COCKS, L.R.M. \& RICKARDS, R.B. (eds) A global analysis of the Ordovician-Silurian boundary. Bulletin of the British Museum (Natural History), Geology 43.

LEgRAND, P. 2003. Paléogeographie du Sahara algérien à l'Ordovicien terminal et au Silurien inférieur. Bulletin de la Société géologique de France 174, 19-32.

LEGRAND, P. \& NABOS, G. 1962. Contribution à la stratigraphie du Cambro-Ordovicien dans le bassin saharien occidental. Bulletin de la Société géologique de France 7, 123-131.

LeSSERTISSEUR, J. 1971. L'énigme du Daedalus (Daedalus Rouault, 1850). Ichnofossilia. Bulletin du Muséum national d'histoire naturelle (Paris) 20, 37-66.

LONG, D.G.F. 2004. Precambrian rivers, 660-663. In ERIKSSON, P.G., Altermann, W., Nelson, D.R., Mueller, W.U. \& Catuneanu, O. (eds) The Precambrian Earth: Tempos and events (Developments in Precambrian geology) 12. Elsevier, Amsterdam.

LÜNING, S., CRAIG, J., LOYDELL, D.K., ŠTORCH, P. \& FITCHES, B. 2000. Lower Silurian 'hot shales' in North Africa and Arabia: regional distribution and depositional model. Earth-Science Reviews 49, 121-200.

Macnaughton, R.B., Dalrymple, R.W. \& Narbonne, G.M. 1997. Early Cambrian braid-delta deposits, MacKenzie Mountains, north-western Canada. Sedimentology 44, 587-609.

MENCHIKOFF, N. 1933. La série primaire de la Saoura et des chaînes d'Ougarta. Bulletin du Service de la Carte géologique d'Algérie 11, 109-123.

MIALL, A.D. 1997. The geology of stratigraphic sequences. 433 pp. Springer-Verlag, Berlin.

MOREAU, J. 2005. Architecture stratigraphique et dynamique des dépôts glaciaires ordoviciens du Bassin de Murzuk (Libye). 192 pp. Thèse de doctorat, Université Louis Pasteur, Strasbourg, France (unpublished).

NIELSEN, A.T. 2004. Ordovician sea level changes: A Baltoscandian perspective, 83-94. In WEBBY, B.D., PARIS, F., DROSER, M. \& PERCIVAL, I. (eds) The Great Ordovician diversification event. Columbia University Press, New York.

NIO, S.-D. \& YANG, C.-S. 1991. Diagnostic attributes of clastic tidal deposits: a review, 3-28. In SMITH, D.G., REINSON, B., ZAITLIN, B.A. \& RAHMANI, R.A. (eds) Clastic tidal sedimentology. Canadian Society of Petroleum Geologists Memoir 16. 
ORGM (OFFICE NATIONAL DE LA RECHERCHE GÉOLOGIQUE) 2000. Kerzaz. Carte géologique de l'Algérie à 1/200.000. Service géologique de l'Algérie, Boumerdès.

OUleBsiR, L. \& PARIS, F. 1995. Chitinozoaires ordoviciens du Sahara algérien: biostratigraphie et affinités paléogéographiques. Review of Palaeobotany and Palynology 86, 49-68.

PARIS, F. 1990. The Ordovician chitinozoan biozones of the Northern Gondwana Domain. Review of Palaeobotany and Palynology 66, 181-209.

Paris, F., Elaouad-Debbaj, Z., Jaglin, J.C., Massa, D. \& OULEBSIR, L. 1995. Chitinozoans and Late Ordovician glacial events on Gondwana, 171-176. In COOPER, D., DROSER, M.L. \& FINNEY, S. (eds) Ordovician Odyssey, Short papers for the seventh international symposium on the Ordovician System. SEPM, Fullerton, California.

PARIS, F., DeYnouX, M. \& GHIENNE, J.-F. 1998. Chitinozoaires de la limite Ordovicien-Silurien en Mauritanie. Comptes rendus de l'Académie des sciences, Paris 326, 499-504.

Paris, F., BoumendJel, K., DABARD, M.P., GHIEnNE, J.-F., LOI, A., TANG, P., VIDET, B. \& ACHAB, A. 2007. Chitinozoan-based calibration of Early-Mid Ordovician transgressive events on northern Gondwana. Acta Palaeontologica Sinica 46, 370-375.

PILlOLA, G.L., LEONE, F. \& LOI, A. 1998. The Cambrian and Early Ordovician of SW Sardinia. Giornale di Geologia (Spec. Issue ECOS VII - Sardinia Guidebook) 60, 25-38.

POSAMENTIER, H.W. 2001. Lowstand alluvial bypass systems: incised vs. unincised. Bulletin American Association Petroleum Geologist 85, 1771-1793.

PoueYTO, A. 1952. Rhyolites et Grès d'Ougarta, Terrains Gothlandiens, 25-47. In ALIMEN, H., LE MAÎTRE, D., MENCHIKOFF, N., Petter, G. \& Poueyto, A. (eds) Les Chaînes d'Ougarta et la Saoura, Monographies Régionales 15. XIX Congrès Géologique International, Alger.

POWELL, R.D. 1990. Sedimentary processes at grounding line fans and their growth to ice-contact deltas, 53-77. In DOWDESWELL, J.A. \& SCOURSE, J.D. (eds) Glacimarine environments: processes and sediments. Geological Society London Special Publication 53.

PRIGMORE, J.K., BUTLER, A.J. \& WOODCOCK, N.H. 1997. Rifting during separation of Eastern Avalonia from Gondwana: evidence from subsidence analysis. Geology 25, 203-206.

Robin, C., Rouby, D., Granjeon, D., Gulllocheau, F., AlleMAND, P. \& RAILLARD, S. 2005. Expression and modelling of stratigraphic sequence distortion. Sedimentary Geology 178, 159-186.

Ross, J.R.P. \& RosS, C.A. 1992. Ordovician sea-level fluctuations, 327-336. In WEBBY, B.D. \& LAURIE, J.R. (eds) Global perspectives on Ordovician geology. Balkema, Rotterdam.

RunKel, A.C., MCKAY, R.M. \& PALMER, A.R. 1998. Origin of a classic cratonic sheet sandstone: stratigraphy across the Sauk II-Sauk III boundary in the Upper Mississippi Valley. Geological Society of America Bulletin 110, 188-210.

Sharland, P.R., ARCHER, R., CASEY, D.M., DAVIES, R.B., HALl, S.H., HEWARD, A.P., HORBURY, A.D. \& SIMMONS, M.D. 2001. Arabian plate sequence stratigraphy. GeoArabia Special Publication 2, 1-371.
Sharland, P.R., CASEy, D.M., DAvies, R.B., Simmons, M.D. \& SUTCLIFFE, O.E. 2004. Arabian plate sequence stratigraphy Revisions to SP 2. GeoArabia 9, 199-214 (chronostratigraphic chart available at http://www.stratigraphy.org/ga_charts.htm).

STAMPFLI, G.M. \& BOREL, G.D. 2002. A tectonic model for the Paleozoic and Mesozoic constrained by dynamic plate boundaries and restored synthetic oceanic isochrones. Earth Planetary Science Letters 196, 17-33.

ŠTORCH, P. 2006. Facies development, depositional settings and sequence stratigraphy across the Ordovician-Silurian boundary: a new perspective from the Barrandian area of the Czech Republic. Geological Journal 41, 163-192.

SutclifFe, O.E., Dowdeswell, J.A., Whittington, R.J., THERON, J.N. \& CRAIG, J. 2000. Calibrating the Late Ordovician glaciation and mass extinction by the eccentricity cycles of Earth's orbit. Geology 28, 967-970.

TAKHERIST, D. 1990. Structure crustale, subsidence mesozö̈que et flux de chaleur dans les bassins nord-sahariens (Algérie): apport de la gravimétrie et des données de puits. 207 pp. Thèse de doctorat, Université de Montpellier (unpublished).

TAugourdeau, P. \& DE JEKHOWSKY, B. 1960. Répartition et description des Chitinozoaires siluro-dévoniens de quelques sondages de la C.R.E.P.S., de la C.F.P.A. et de la S.N. Repal au Sahara. Revue de l'Institut Français du Pétrole 15, 1199-1260.

VAil, P.R., Audemard, F., Bowman, S.A., EISNer, P.N. \& PEREZ-CRUZ, C. 1991. The stratigraphic signatures of tectonics, eustasy and sedimentology - an overview, 617-659. In EINSELE, G., RICKEN, W. \& SEILACHER, A. (eds) Cycles and events in stratigraphy. Springer-Verlag, Berlin.

VECOLI, M. 1999. Cambro-Ordovician palynostratigraphy (acritarches and prasinophytes) of the Hassi-R'Mel area and northern Rhadames Basin, North Africa. Palaeontographia Italica $86,1-112$.

Vecoli, M., Albani, R., GHomari, A., MASSA, D. \& Tongiorgi, M. 1995. Précisions sur la limite Cambrien-Ordovicien au Sahara Algérien (Secteur de Hassi-R'mel). Comptes rendus de l'Académie des sciences, Paris 320, 515-522.

VeCOLI, M. \& LE HÉRISSÉ, A. 2004. Biostratigraphy, taxonomic diversity and patterns of morphological evolution of Ordovician acritarchs (organic-walled microphytoplankton) from the northern Gondwana margin in relation to palaeoclimatic and palaeogeographic changes. Earth Science Reviews 67, 267-311.

VeColi, M., PARIS, F. \& Videt, B. 2007. "Middle" Cambrian non-marine organic walled microfossils from the Algerian Sahara and their implications for the debate on the nature and origin of cryptospores. Geophysical Research Abstracts 9. EGU General Assembly 2007, Vienna, Austria.

WADE, B.S. \& PÄLIKE, H. 2004. Oligocene climate dynamics. Paleoceanography 19(4), PA4019.

WEBBy, B.D., COOPER, R.A., BERGSTRÖM, S.M. \& PARIS, F. 2004. Stratigraphic framework and time slices, 41-47. In WEBBY, B.D., PARIS, F., DROSER, M. \& PERCIVAL, I. (eds) The Great Ordovician diversification event. Columbia University Press, New York. 